\title{
Combating Global Climate Change: Why a Carbon Tax Is a Better Response to Global Warming Than Cap and Trade
}

\author{
Reuven S. Avi-Yonah
}

David M. Uhlmann*

I. The Global Climate Change CRISIS AND THE INADEQUACy OF HISTORICAL EFFORTS TO COMBAT GLOBAL WARMING .................. 9

A. Overview of the Global Climate Change Crisis .................. 9

B. The Inadequacy of Historical Efforts to Address

Greenhouse Gas Emissions and Global Warming ............ 14

II. The LeAding Alternatives for Reducing CARbon Dioxide

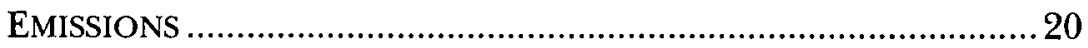

A. Regulatory Limits on Carbon Dioxide Emissions ............. 21

1. A National Ambient Air Quality Standard for Carbon Dioxide Under Title I of the Clean Air Act ...............22

2. Carbon Dioxide Emission Standards for Motor Vehicles Under Title II of the Clean Air Act...............24

3. Permits for Major Sources of Carbon Dioxide Emissions Under Title V of the Clean Air Act ............27

B. Market-Based Limits on Carbon Dioxide Emissions......... 28

* Reuven S. Avi-Yonah is the Irwin I. Cohn Professor of Law and the Director of the International Tax LLM Program at the University of Michigan Law School; David M. Uhlmann is the Jeffrey F. Liss Professor from Practice and the Director of the Environmental Law and Policy Program at the University of Michigan Law School. The authors wish to thank Michael Barr, David Duff, Kyle Logue, Nina Mendelson, Virginia Murphy, Peter Murtha, and Barry Rabe for reviewing drafts of this article and Kyle Landis-Marinello and Andrew Moore for providing outstanding research assistance. 
1. The Benefits of Market-Based Limits .29

2. Upstream Versus Downstream Market-Based Limits.. 31

3. Key Features of a Carbon Tax and Cap and Trade .... 32

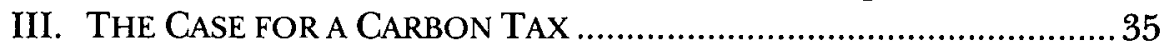

A. The Theoretical Tradeoff............................................. 35

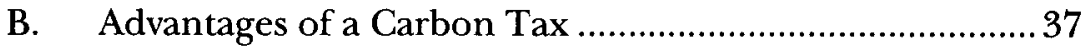

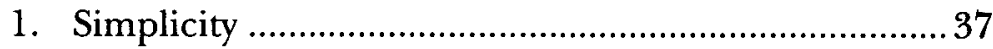

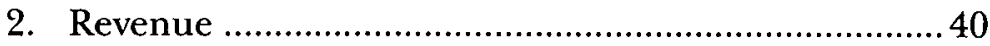

3. Cost Certainty .................................................... 42

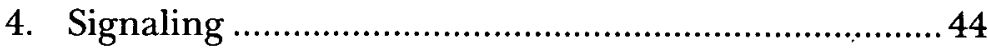

C. Disadvantages of a Carbon Tax....................................... 45

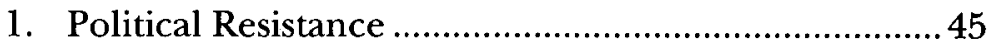

2. Benefit Uncertainty ...............................................46

3. Tax Exemptions................................................. 47

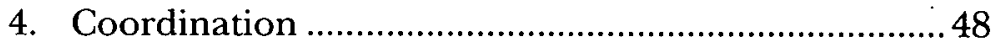

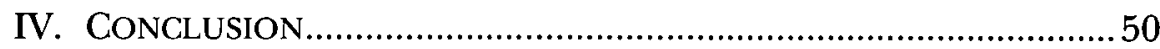

We must work together to safeguard our future-the future of mankind. To find the way for a common work for a common goal there is no need for a revolution. There is need merely of deep knowledge, of objective thought, of constructive discussion, and of willingness for understanding.

Hugo Boyko ${ }^{1}$

Global climate change is the most significant environmental issue facing our nation and the world. There no longer is any question that global warming is occurring. Nor is there any serious debate about whether human activity is the root cause. If we fail to make significant reductions in greenhouse gas emissions over the next ten to twenty years, we face the possibility of catastrophic environmental harm by the end of this century.

1. Hugo Boyko, Introduction to SCIENCE AND THE FUTURE OF MANKIND 7 (Hugo Boyko ed., 1961). Hugo Boyko was a pioneer in global ecology and the founder and first Secretary-General of the World Academy of Art and Science. The first author (his grandson) would like to dedicate his contribution to this article to his memory. 
The leading proposal in the United States and abroad for addressing global climate change is some form of market-based cap and trade system. During the 2008 presidential campaign, both major party candidates supported cap and trade. ${ }^{2}$ Many of the mainstream environmental groups advocate cap and trade and, in an unusual alliance, their position is shared by many industry. groups. A cap and trade system therefore is likely to be the focal point of domestic legislation during the Obama Administration and whatever international agreement follows the Kyoto Protocol, which expires in 2012.

The popularity of a cap and trade system may reflect the fact that cap and trade offers something for everyone. For environmentalists, cap and trade promises a declining cap on the carbon dioxide emissions that are the principal cause of global warming. For industry groups, cap and trade offers the possibility of a new market in carbon allowances and therefore the potential for significant income for companies who can inexpensively reduce their carbon dioxide emissions. For economists, cap and trade allows the market to take into account externalities as it determines the price of carbon. For politicians, cap and trade offers the opportunity to take action to combat global warming without implementation of a complex regulatory permitting scheme or imposition of a tax on fossil fuels.

The global climate change crisis calls for innovation from industry to meet the challenge of carbon dioxide emissions reductions and promote the development of alternative energy sources. It is essential that the United States and the world take strong and decisive action to reduce greenhouse gas emissions. A cap and trade system offers the benefit of increasing limits on carbon dioxide emissions and, at least theoretically, a flexible approach that allows the market to select the most efficient and innovative car-

2. Andrew C. Revkin, On Global Warming, McCain and Obama Agree: Urgent Action Is Needed, N.Y. TIMES, Oct. 19, 2008, at A2. While both candidates supported adoption of a cap and trade system, they disagreed about when credits should be auctioned and the levels at which reductions should occur, just two of the issues that could make a cap and trade system difficult to implement, administer, and enforce. 
bon dioxide reduction techniques and thus lower the cost of any required carbon dioxide emission reductions. ${ }^{3}$

The popular and intellectual appeal of a cap and trade system, however, obscures a number of practical considerations that, at a minimum, counsel against cap and trade as the leading edge of domestic efforts to combat climate change. First, even if Congress passed cap and trade legislation early in the Obama Administration, it would be years before a cap and trade system would become operational, because of the inherent delays of the rulemaking process (including the likelihood of litigation over whatever regulatory system is adopted). Second, the effectiveness of a cap and trade system could be undermined by the challenges of setting baselines for emission reduction targets, the free distribution of allowances, and the use of offsets in lieu of meaningful emission reduction measures. Third, while a cap and trade system promises fixed reductions in carbon dioxide emissions, the tradeoff is uncertainty about the price of those reductions. If the price of carbon rises too high, there will be political pressure to relax the carbon cap, thus removing the primary benefit of a cap and trade system.

Moreover, an international environmental crisis is not the best time to experiment with a largely untested emissions control system on a global scale. It is far from clear that a cap and trade system for carbon dioxide emissions will work on a national and international level. While the United States utilized a cap and trade system to reduce acid rain in the $1990 \mathrm{~s},{ }^{4}$ we have never used cap and trade to address an emissions problem that involves such a wide variety of sources, nor do we have experience with a global cap and trade system.

A more efficient and effective market-based approach to reduce carbon dioxide emissions would be a carbon tax imposed on

3. See Richard B. Stewart and Jonathan B. Wiener, Reconstructing Climate POLICY 67-68 (2003) (arguing that cap and trade programs, as well as emission taxes, provide continuing financial incentives to adopt new, less costly abatement methods). For a contrary view, see David M. Driesen, Does Emissions Trading Encourage Innovation?, [2003] 33 Envtl. L. Rep. (Envtl. Law Inst.) 10094 (claiming that emissions trading provides less stimulation for innovation than traditional regulation).

4. Clean Air Act Amendments of 1990, Pub. L. No. 101-549, Title IV, § 401, 104 Stat. 2584 (codified as amended at 42 U.S.C. $\$ \S 7651-76510$ ). The United States also used aspects of a cap and trade system during the phase-out of leaded gasoline in the $1970 \mathrm{~s}$. 
all coal, natural gàs, and oil produced domestically or imported into the United States. A carbon tax would enable the market to account for the societal costs of carbon dioxide emissions and thereby promote emission reductions, just like a cap and trade system. A carbon tax would be easier to implement and enforce, however, and simpler to adjust if the resulting market-based changes were either too weak or too strong. A carbon tax also would produce revenue that could be used to fund research and development of alternative energy and tax credits to offset any regressive effects of the carbon tax. Because a carbon tax could be implemented and become effective almost immediately, it would be a much quicker method of reducing greenhouse gas emissions than a cap and trade system. In addition, because a carbon tax could be effective in advance of any international treaty regarding greenhouse gas emissions, a carbon tax would provide the United States much needed credibility in the negotiations over international carbon dioxide limits. A carbon tax could then supplement an international cap and trade system, combine with emission caps in an international hybrid "cap and tax" approach, or become the focal point for the next international treaty to address global climate change.

A carbon tax carries its own practical limitations, perhaps the most significant of which is the challenge of enacting tax legislation in the United States. Those political considerations may be compounded by instability in energy prices (which peaked at over $\$ 140$ per barrel during the summer of 2008 , only to fall below $\$ 50$ per barrel by November 2008) and economic concerns created by the global credit crisis during the fall of 2008. A cap and trade system may be more viable politically, because it is not labeled a tax nor is it as transparent about its effect on energy prices. The political advantages of cap and trade may be more illusory than real, however, since opponents of climate change legislation will argue that either approach would increase energy costs and further damage an already weakened economy. ${ }^{5}$ Moreover, while climate

5. Stephen Power \& Leila Abboud, Climate Effort Could Be Stalled by Credit Crisis, WALL ST. J., Oct. 16, 2008, available at http://online.wsj.com/article/SB122411508399938601 .html\#articleTabs \%3Darticle. 
change legislation will be difficult to enact during a possible recession, the climate change crisis will worsen and become more costly to address if Congress fails to enact limits on greenhouse gas emissions early in the Obama Administration. ${ }^{6}$

Part I of this Article reviews the global climate change crisis and the inadequacy of historical efforts to combat global warming. This overview demonstrates the need for strong and immediate action to address climate change after such a long history of relative inaction, particularly in the United States. Part II discusses alternatives for reducing greenhouse gas emissions, specifically carbon dioxide. We focus on traditional regulatory approaches under existing provisions of the Clean Air Act, since those would be easier to implement than a new statutory scheme. We conclude that an "upstream" market-based approach that targets fossil fuel production, perhaps in combination with selected regulatory controls under the Clean Air Act, would make the most sense for reducing carbon dioxide emissions across all sectors of the economy.

Part III explains why a carbon tax would be a-more effective market-based response to global climate change than a cap and trade system. This Part argues that both a carbon tax and cap and trade system incorporate the necessary carbon price signal, with a tax offering "price certainty" and cap and trade offering "benefit certainty," but asserts that a carbon tax would be simpler to implement, more transparent, and less vulnerable to abuse. A carbon tax would also generate needed revenue to support development of alternatives to fossil fuels, and it would send a stronger message about the perils of carbon dioxide emissions. Part IV concludes by suggesting that, while fundamental changes also must occur in energy, transportation, and land use policy, an effective mitigation strategy for carbon dioxide emissions will be the centerpiece of any successful program to combat global climate change.

6. We are not suggesting that climate change mitigation must be justified through cost-benefit analysis, which provides a poor analytical fit because of uncertainty about the long-term societal and ecological costs associated with climate change. See generally Douglas A. Kysar, Climate Change, Cultural Transformation, and Comprehensive Rationality, 31 B.C. ENVTL. AFF. L. REV. 555 (2004). To the extent that opposition to climate change mitigation efforts focuses on economic costs, however, it merits emphasis that the costs of a carbon tax (or a cap and trade system) will be dwarfed by the costs of failing to take effective measures to combat climate change, and those costs will escalate over time. 


\section{The Global Climate Change Crisis and the InadequaCy of HiSTORICAL EFFORTS TO COMBAT GLOBAL WARMING}

For more than forty years, scientists have expressed concern about growing carbon concentrations in the atmosphere and resulting global climate change. Public concern has lagged behind the scientific evidence, and our political leaders have been even slower to recognize the magnitude of the climate change crisis. In the past several years, however, with the release of An Inconvenient Truth $^{7}$ and mounting evidence of global warming, the political debate about the existence of global climate change has largely ended-only to be replaced by the more difficult question of what to do about climate change. ${ }^{8}$

This Part of the Article begins with an overview of the evidence that climate change is occurring and the steps that must be taken to avoid its most catastrophic effects. It then reviews historical efforts to address climate change and the inadequacy of those measures to reduce greenhouse gas emissions and thereby avert a global climate change crisis.

\section{A. Overview of the Global Climate Change Crisis}

The scientific evidence that global warming is occurring is overwhelming. In 1988, the United Nations Environmental Programme and the World Meteorological Organization formed the Intergovernmental Panel on Climate Change (the IPCC) to provide objective scientific analysis on all aspects of climate change. The most recent IPCC report, released in November 2007, concluded that "[e]leven of the last twelve years (1995-2006) rank among the twelve warmest years in the instrumental record of global surface temperatures (since 1850)." The IPCC reported

7. AN INCONVENIENT TRUTH (Paramount Classics 2006).

8. E.g., EdWARd A. PARSON ET AL., Global-CHANGE SCENARIOS: REPORT BY THE U.S. Climate Change Science Program and the Subcommittee on Global Change RESEARCH 10 (2007), available at http://www.climatescience.gov/Library/sap/sap2-1/ finalreport/sap2-1b-final-all.pdf.

9. Intergovernmental Panel on Climate Change, Cllimate Change 2007: SYNTHESIS REPORT, SUMMARY FOR POLICYMAKERS 1 (2007) [hereinafter IPCC REPORT]. The November 2007 IPCC report reflected the efforts of more than 500 lead authors and 2,000 expert reviewers. The report was released too early to account for 2007 temperatures, but a recent study found that 2007 was tied with 1998 as the second hottest year on 
that temperature increases have occurred throughout the world, but most significantly at higher northern latitudes. ${ }^{10}$

The melting of Arctic ice has often been called "the canary in the coal mine" of global warming. ${ }^{11}$ In 2007, Arctic ice melted at record levels, causing the opening of the fabled Northwest Passage to navigation for the first time. ${ }^{12}$ During the same summer, a record 552 billion tons of ice melted from the Greenland ice sheet. ${ }^{13}$ It is hard to overstate the significance of melting in Greenland. If global warming continues unabated, climatologists predict that the entire Greenland ice sheet will melt, causing several meters of sea level rise and coastal flooding that could imperil much of the eastern United States. ${ }^{14}$

While some skeptics argue that global warming is part of normal climate change, ${ }^{15}$ few climatologists agree. The earth has experienced periods of cooling and warming over time, but warming has never occurred at the rate that it is happening today. The most recent IPCC report noted that " $[\mathrm{m}]$ ost of the observed increase in global average temperatures since the mid-20th century is very likely due to the observed increase in anthropogenic [greenhouse gas] concentrations."

Anthropogenic greenhouse gases include carbon dioxide, methane, nitrous oxide, hydrofluorocarbons, perfluorocarbons,

record; the hottest year was 2005. GODDARD INST. FOR SPACE STUDIES, NAT'L AERO. \& SPACE ADMIN., GlobAl TEMPERATURE TRENDS: 2007 SUMmATION, http://data.giss.nasa.gov /gistemp/2007/ (last visited Mar. 10, 2008).

10. Id. at 2.

11. NASA climate scientist $H$. Jay Zwally, commenting on the melting of the Arctic Ocean, stated in December 2007 that " $[t]$ he Arctic is often cited as the canary in the coal mine for climate warming. Now ... the canary has died. It is time to start getting out of the coal mines." Seth Borenstein, Rate of Ice Melting Shocks Warming Experts, ASsociaTED PRESS, Dec. 11, 2007, http://www.msnbc.msn.com/id/22203980. at 12.

12. Laurie Goering, Ice-Free Arctic in Summer Seen in 7 Years, CHI. TRIB., Dec. 14, 2007,

13. Borenstein, supra note 11 (citing preliminary satellite data to be released by NASA).

14. IPCC REPORT, supra note 9 , at 13.

15. See, e.g., S. Fred Singer \& DenNis T. Avery, UnStOPPable Global WaRming EVERY 1,500 YEARS (2007).

16. IPCC REPORT, supra note 9, at 5 . As used by the IPCC, the term "very likely" corresponds to a greater than ninety percent probability of occurrence. INTERGOVERNMENTAL PANEl ON Climate CHANGe, Climate CHANGE 2007: SYNTHESIS REPORT 27 (2007) [hereinafter IPCC SYNTHESIS REPORT]. 
and sulfur hexafluoride. Carbon dioxide is by far the most significant of the greenhouse gases, accounting for approximately seventy-five percent of anthropogenic greenhouse gas emissions between 1970 and $2004 .{ }^{17}$ Annual global emissions of carbon dioxide increased "almost fivefold in the past century," and these emissions "have tripled since 1950." 18 The most significant contributing factor in the carbon dioxide emissions increase is the burning of fossil fuels for electricity, heating, air conditioning, and transportation; land-use changes, particularly deforestation, also have played a significant but smaller role. ${ }^{19}$

Historically, the United States is the largest contributor to global warming, responsible for approximately twenty-five percent of global carbon dioxide emissions. ${ }^{20}$ China now emits as much greenhouse gas as the United States, ${ }^{21}$ and India is not far behind, ${ }^{22}$ but the United States remains well ahead of these countries in per capita greenhouse gas emissions. ${ }^{23}$ Moreover, in terms of cumulative greenhouse gas emissions, the United States is by far the world leader; ${ }^{24}$ no other nation comes close.

17. See IPCC REPORT, supra note 9, at 5 fig.SPM.3. This percentage includes carbon dioxide released as a result of deforestation.

18. JaMes Gustave SPETH, RED SKY AT MORNING: AMERICA AND THE CRISIS OF THE GLOBAL ENVIRONMENT 45 (2004).

19. E.g., IPCC REPORT, supra note 9 , at 5 fig.SPM.3.

20. E.g., NAT'L ACAD. OF SCI. ET AL., Understanding and Responding to Climate Change 18 fig. 12 (2005), available at http://dels.nas.edu/dels/rpt_briefs/climate-change-final.pdf.

21. E.g., Neth. ENVTL. ASSESSMENT AGENCY, CHINA Now No. 1 IN CO2 Emissions; USA IN SECOND POSITION (2008), http://www.mnp.nl/en/dossiers/Climatechange/more info/ChinanownolinCO2emissionsUSAinsecondposition.html (2008).

22. See generally P.R. SHUKLA ET AL., ClimATE POLICY ASSESSMENT FOR INDIA 142 (2004) (predicting major increases in the amount of energy needed to fuel India by 2030 and predicting that coal will likely fill much of this need).

23. For instance, in 1991, the per capita greenhouse gas emissions in the United States were approximately thirty times larger than the per capita emissions in India. Jyoti Parikh, India's Efforts to Minimize Greenhouse Gas Emissions: Policies, Measures, and Institutions, in INDia AND Global Climate Change 333, 334 (Michael A. Toman, Ujjayant Chakravorty, \& Shreekant Gupta eds., 2003).

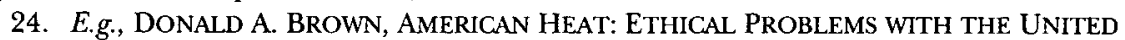
STATES' RESPONSE TO GLOBAL WARMING 156 (2002). The United States is responsible for thirty percent of cumulative greenhouse gas emissions; the United States emits the same amount of greenhouse gases as 2.6 billion people living in 151 developing countries. SPETH, supra note 18 , at 61 . 
Compounding the climate change problem is the fact that greenhouse gas emissions continue to grow at an alarming rate. If greenhouse gas emissions were to remain at current levels, many parts of the world still might be uninhabitable by the end of the century. ${ }^{25}$ Yet the global rate of greenhouse gas emissions is not stabilizing; it is accelerating. The rate of global greenhouse gas emissions due to human activity grew by seventy percent between 1970 and $2004 .{ }^{26}$ With the rapid industrialization of China and India, and absent efforts to control greenhouse gas emissions there and in the rest of the world, carbon dioxide emissions are projected to grow by fifty-five percent globally between 2004 and $2030 .^{27}$

One of the cruel ironies of the climate change crisis is that developed countries like the United States have contributed the most to global warming, ${ }^{28}$ yet less developed countries will suffer the worst ill effects. ${ }^{29}$ Part of the challenge facing less developed countries is that many of them are located in regions of the world where natural resources, most notably water and food supplies, are scarce even without the detrimental effects of global climate change. ${ }^{30}$ In addition, both because of those natural resource limitations and economic constraints, less developed countries will be less able to adapt to climate change when it occurs. ${ }^{31}$

Significant reductions in greenhouse gas emissions must occur during the next ten to twenty years to avoid the worst consequences of global warming. Climatologists warn that we must limit

25. JaMES GuSTAVE SPETH, THE BRIDGE AT THE EDGE OF THE WORLD: CAPITAlism, THE ENVIRONMENT, AND CROSSING FROM CRISIS TO SUSTAINABILITY, at x (2008).

26. IPCC REPORT, supra note 9 , at 5 . The rate of greenhouse gas emissions in the United States increased by over sixteen percent between 1990 and 2005. John Donnelly, EPA Reports a Rise in Greenhouse Gases, BOSTON GLOBE, Feb. 21, 2007, at 9A; U.S. DEP'T OF ENERGY, ENERGY INFO. ADMIN., EMISSIONS OF GREENHOUSE GASES, 1980-2006, http://www.eia.doe.gov/emeu/aer/txt/ptb1201.html (last visited Mar. 10, 2008).

27. SPETH, supra note 25, at 27 (citing INTERNATIONAL ENERGY AGENCY, WORLD ENERGY OUTLOOK, 2006 (2006)). The IPCC projects an increase of twenty-five to ninety percent between 2000 and 2030 . IPCC REPORT, supra note 9 , at 7.

28. BROWN, supra note 24 , at 156 ("[T] he developed nations have contributed 84 percent of the greenhouse gas emissions from 1800 to the present.").

29. E.g., id. at $92-94$.

30. See id. at 93 .

31. Id. at $93-94$. 
global warming to approximately $2^{\circ} \mathrm{C}$ or $4^{\circ} \mathrm{F}$ to avoid catastrophic environmental effects. ${ }^{32}$ To put these numbers in perspective, average temperatures have only varied by $1.8^{\circ} \mathrm{F}$ during the last 10,000 years. Since the end of the last ice age, average temperatures have only increased by 5 to $9^{\circ} \mathrm{F}^{33}$

To limit global warming to $2^{\circ} \mathrm{C}$ or $4^{\circ} \mathrm{F}$ will require stabilizing carbon dioxide concentrations in the atmosphere at around 450 parts per million (ppm), and some recent analyses recommend stabilizing at $400 \mathrm{ppm}$ or even lower to prevent going above this temperature threshold. ${ }^{34}$ To put those targets in context, preindustrial carbon concentrations in the atmosphere were $280 \mathrm{ppm}$; today, carbon concentrations in the atmosphere are approximately $380 \mathrm{ppm}$, which is higher than the natural range over the last 650,000 years. $^{35}$ At current rates carbon concentrations will increase by 2 ppm each year, which means that, without reductions in carbon dioxide emissions, carbon concentrations will reach 450 ppm before the middle of this century. Unfortunately, unless we take steps to reduce carbon dioxide emissions, we are likely to reach $450 \mathrm{ppm}$ even sooner, because, as noted above, the rate of carbon dioxide emissions is increasing so rapidly. ${ }^{36}$

Perhaps the most sobering aspect of the climate change problem is the long lag time for reducing carbon dioxide concentrations in the atmosphere. Carbon dioxide in the atmosphere re-

32. See, e.g., Rachel Warren, Impacts of Global Climate Change at Different Annual Mean Global Temperature Increases, in AvOIDING DANGEROus Climate CHANGE 93, 93-100 (Hans Joachim Schellnhuber et al. eds., 2006) (noting that surpassing a $2^{\circ} \mathrm{C}$ increase in global annual mean temperatures will cause millions of people to be displaced, go hungry, be exposed to increased risk of malaria and other diseases, and experience increased water stress, and that at such temperatures Arctic ecosystems will begin to collapse, leading many species-including polar bears-to go extinct).

33. UNION OF CONCERNED SCIENTISTS, Global WARMING SCIENCE: GLOBAL WARMING FAQ http://www.ucsusa.org/global_warming/science_and_impacts/science/ global-warming-faq.html (last visited Mar. 10, 2008).

34. E.g., Bert Metz \& Detlef van Vuuren, How, and at What Costs, Can Low-Level Stabilization Be Achieved?-An Overview, in Avolding Dangerous Climate Change 337, 337 (Hans Joachim Schellnhuber et al. eds., 2006).

35. IPCC SYNTHESIS REPORT, supra note 16 , at 37.

36. The worst case scenario in the most recent IPCC Synthesis Report shows greenhouse gas emissions stabilizing at the equivalent of $1,550 \mathrm{ppm}$ of atmospheric carbon dioxide. Id. at 45 tbl.3.1 n.c. 
mains for many decades or even centuries. ${ }^{37}$ As a result, we are unlikely to see the positive effects of any reductions in carbon dioxide emissions until the second half of this century. ${ }^{38}$ To put it differently, the damage we already have done cannot be mitigated for nearly half a century; our best hope in the near term is to take sufficient steps to limit further damage and to protect ourselves from the catastrophic effects that could occur.

\section{B. The Inadequacy of Historical Efforts to Address Greenhouse Gas Emissions and Global Warming}

The magnitude of the global warming problem has increased because of the alarming failure of past efforts to reduce greenhouse gas emissions and prevent further warming. While public and political attention to global climate change has reached a point where action now is possible, scientists have issued warnings about the dangers of an excess buildup of greenhouse gases for more than a century. An Irish physicist named John Tyndall began researching the atmospheric effects of carbon dioxide nearly 150 years ago. ${ }^{39}$ Around the turn of the twentieth century, Swedish chemist Svante Arrhenius asserted that increasing levels of atmospheric carbon dioxide would lead to higher global temperatures. ${ }^{40}$

In the decades that followed, other European scientists explored the possible climatic effects of burning fossil fuels, and by the 1950 s a number of prominent American scientists had begun

37. See, e.g., NAT'L ACAD. OF SCI. et al., supra note 20, at 16.

38. E.g., Nicholas STERN, THE STERn Review: THE ECONOMics of Climate CHANGE i (2007), available at http://www.hm-treasury.gov.uk/media/4/3/Executive

Summary.pdf ("The effects of our actions now on future changes in the climate have long lead times. What we do now can have only a limited effect on the climate over the next 40 or 50 years.").

39. E.g., Tyndall Centre for Climate Change Research, Biography of John Tyndall, FRS, DCL, LLD, http://www.tyndall.ac.uk/general/history/john_tyndall_biography.shtml (last visited Sept. 26, 2008). See also ELIZABETH KOLBERT, FIELD NOTES FROM A CATASTROPHE: MAN, NATURE, AND ClimATE ChANGE 35-36 (2006).

40. E.g., Patricio A. Bernal, Preface to GuY JacQues \& Hervé Le Treut, Climate CHANGE 5 (2005). Arrhenius's calculations in 1896 were later found to be surprisingly accurate, although he erred greatly in assuming that it would take thousands of years for humans to double the amount of atmospheric carbon dioxide. BROWN, supra note 24 , at 14. 
similar research. ${ }^{41}$ A 1963 meeting of the Conservation Foundation concluded that increased carbon dioxide emissions would lead to a significant temperature increase. ${ }^{42}$ By 1965, President Lyndon B. Johnson told Congress that humans have "altered the composition of the atmosphere on a global scale through . . . a steady increase in carbon dioxide from the burning of fossil fuels." ${ }^{43}$ A year later, the National Academy of Sciences concluded that carbon dioxide increases could lead to "inadvertent weather modification." Warnings continued throughout the 1970 s, and in 1979, the National Academy of Sciences published the Charney Report, which concluded "[i]f carbon dioxide continues to increase, the study group finds no reason to doubt that climate changes will result and no reason to believe that these changes will be negligible." ${ }^{45}$

By the early 1980s, many scientists believed that greenhouse gases threatened to bring about a dangerous global warming trend, and these scientists and the scientific organizations that supported them tried to persuade government officials to pay attention to the issue. ${ }^{46}$ By 1985 , "growing scientific evidence" of climate change placed the issue on the political agenda. ${ }^{47}$ When the World Commission on Environment and Development (later known as the Brundtland Commission) published Our Common Future in 1987, climate change from carbon dioxide emissions was listed first among four "disturbing" environmental risks associated

41. E.g., Naomi Oreskes, The Long Consensus on Climate Change, WASH. POST, Feb. 1, 2007 , at $\mathrm{A} 15$.

42. Clive L. Spash, GReEnhouse ECONOMICS 12 (2002).

43. Oreskes, supra note 41 , at A15.

44. Id.

45. NAT'L ACAD. OF SCI., CARBON DIOXIDE AND CLIMATE: A SCIENTIFIC ASSESSMENT viii (1979). The Charney Report was prepared by the National Academy of Sciences after Congress enacted the National Climate Program Act of 1978, Pub. L. No. 95-367, 92 Stat. 601 (codified as amended at 15 U.S.C $\$ \S 2901-08$ (Westlaw 2008)), which directed the President to further study potential climate change.

46. ANDREW E. DESSler \& EdWARd A. PARSOn, THE ScIENCE and Politics of Global Climate Change 12 (2006); see also SPETH, supra note 18, at 55 ("For the past quarter-century, the international scientific community and others have been sounding ever-louder warnings that earth's climate, the climate that has sustained natural and human communities throughout history, is now seriously threatened by atmospheric pollution.").

47. Bernal, supra note 40, at 5; accord SPASH, supra note 42, at 13 (noting that a "scientific consensus" had developed in 1985). 
with our high energy use. ${ }^{48}$ The Commission also noted that "we already know enough to warrant action" on global threats such as climate change and stated that it was "urgent" that countries begin working on international agreements to reduce greenhouse gases. $^{49}$

The scientific studies of the 1970s and 1980s did not result in significant action by the United States to combat global climate change. Congress passed the National Climate Program Act in $1978,{ }^{50}$ which directed the President to establish a program to "understand and respond" to potential global climate change and resulted in the Charney Report, which predicted significant climate change if carbon dioxide emissions continued to increase. ${ }^{51}$ In 1987, Congress passed the Global Climate Protection Act, which required EPA to propose a "coordinated national policy on global climate change," ${ }^{22}$ in essence nothing more than had been mandated a decade earlier by the National Climate Program Act.

In 1988, the United States experienced a heat wave and an ensuing drought, which happened to coincide with a hearing by the Senate Committee on Energy and Natural Resources on the greenhouse effect. ${ }^{53}$ The chief expert witness was NASA scientist Dr. James Hansen, who stated that-based upon his own studies as well as a comprehensive review of scientific research-he was ninety-nine percent certain that human activities were leading to increased global temperatures. ${ }^{54}$ Dr. Hansen's testimony has been described in the following manner:

[A]fter several other authorities supported [Dr. Hansen's] findings, forecast a wide range of effects (none pleasant), and called for strong action to reduce fossil fuel emissions[,] reporters gathered around the table asking questions. In response to one query,

48. REPORT OF THE WORLD COMM'N ON ENV'T AND DEV.: OUR COMMON FUTURE ch. 7, II 11 (1987), available at http://www.un-documents.net/wced-ocf.htm.

49. Id. at ch. 1, I 32, ch. 7, I 23.

50. See National Climate Program Act, supra note 45.

51. See Charney Report, supra note 45.

52. Pub. L. No. 100-204, Title XI, $\S 1103($ b), 101 Stat. 1407 (1987) (codified in note following 15 U.S.C $\$ 2901$ (Westlaw 2008)).

53. E.g., BLLl MCKIBBEN, THE END OF NATURE 23 (1989).

54. Id. at 24 . 
Hansen said, "It's time to stop waffling so much. It's time to say the earth is getting warmer. ${ }^{n 5}$

The United Nations established the Framework Convention on Climate Change (UNFCCC) in 1990, which led to the adoption of an international treaty at the 1992 Earth Summit in Rio de Janeiro-the precursor to the Kyoto Protocol. ${ }^{56}$ Throughout the UNFCCC negotiations, the United States made clear that it was opposed to enforceable reduction targets, since President George $\mathrm{H}$. W. Bush was unwilling to agree to any measures that might jeopardize the United States economy or lifestyle. ${ }^{57}$ Although momentum had been building toward mandatory reductions in greenhouse gases, the United States exerted its influence to limit the scope of the Rio agreement and avoid committing to any mandatory reductions. ${ }^{58}$

The 1997 Kyoto Protocol was the first international agreement with mandatory limits on greenhouse gas emissions. ${ }^{59}$ Under the Kyoto Protocol, developed nations agreed to decrease their emissions by 2012 by at least five percent below 1990 levels on average. ${ }^{60}$ Once more, however, the United States objected to mandatory emission controls based on economic concerns. ${ }^{61}$ The United States was particularly vocal in its protests about the lack of mandatory limits on the emissions of developing nations. ${ }^{62}$ Although the

55. Id. at 26.

56. The non-binding UNFCCC agreement signed in 1992 sought to reduce greenhouse gas emissions to 1990 levels. United Nations Framework Convention on Climate Change art. 4(2) (b), May 9, 1992, 31 I.L.M. 849 (entered into force Mar. 21, 1994).

57. BROWN, supra note 24 , at 23.

58. SPASH, supra note 42, at $17-18$; see also BROWN, supra note 24 , at 19 (noting that the United States "often resist[ed] proposals that had the support of many nations") ; Fred Pearce, The last Generation: How Nature Will Take Her Revenge for Climate CHANGE 15 (2007) (referring to the 1992 Earth Summit as representing a "fail[ure] to act decisively").

59. Introduction to Kyoto Protocol to the United Nations Framework Convention on Climate Change, Dec. 10, 1997, 37 I.L.M. 22 (entered into force Feb. 16, 2005).

60. See id. at art. 3.

61. E.g., BROWN, supra note 24, at 34 ("Just as in the 1992 Earth Summit negotiations, the United States entered the Kyoto negotiations holding, along with Australia, the least environmentally protective position among major players. . . President Clinton had been convinced by his economic advisers to go slow because of potential adverse economic impacts on the U.S. economy if the proposals of other nations were adopted at Kyoto.").

62. E.g., id. at 32 . 
United States made the symbolic gesture of signing the agreement, it did so only while stating that it would not submit the agreement to the United States Senate for ratification until major developing countries agreed to do more. ${ }^{63}$ Indeed, at the time it would have been futile to submit the agreement for ratification, since the Senate had already stated in a 95-0 Resolution that it was the "sense of the Senate" that the United States should not sign any agreement that did not require developing countries to limit their own emis'sions. ${ }^{64}$

During the Bush Administration, the United States did not relent in its opposition to mandatory limits on greenhouse gas emissions. President George W. Bush publicly stated his opposition to the Kyoto Protocol, ${ }^{65}$ which prompted a fierce international reaction, ${ }^{66}$ as might have been expected since over 175 other countries-representing near unanimity throughout the entire worldhave ratified the protocol. ${ }^{67}$ The United States and Kazakhstan are the only countries that signed but have not ratified the Kyoto Protocol.

Although the Kyoto Protocol was an important step in the right direction, commentators have noted that it was "but a baby step in reducing world carbon use and output." ${ }^{\circ 8}$ Since 1997, the international community has had regular meetings to find agreement on additional limits on emissions and to extend the reduction requirements beyond 2012. The 2001 meeting of the United Nations Climate Change Convention resulted in the Marrakech Accords, which recognized the need for going beyond the steps taken in the Kyoto Protocol, although it fell far short of mandating the much larger reductions that many scientists say are needed. ${ }^{69}$

63. JACQUES \& LE TREUT, supra note 40, at 132.

64. S. Res. 98, 105th Cong. (1997) (enacted).

65. E.g., SPASH, supra note 42 , at 18 (" $[\mathrm{T}]$ he election of Bush (junior) immediately led to the US administration boycotting the Protocol. ...").

66. E.g., BROWN, supra note 24 , at 40.

67. United Nations, Kyoto Protocol Status of Ratification, http://unfccc.int/kyoto_ protocol/background/status_of_ratification/items/2613.php (last visited Mar. 10, 2008).

68. GARY BRAASCH, EARTH UNDER FIRE: HOW GLOBAL WARMING IS CHANGING THE WORLD 176 (2007).

69. See U.N. Framework Conv. on Climate Change [UNFCCC], The Marrakech Accords and the Marrakech Declaration, U.N. Doc. FCCC/CP/2001/13/Add.2 (Oct. 11, 2001), avail- 
The most significant efforts to control greenhouse gas emissions have occurred in the European Union, which has also initiated its own climate policy. The European Union climate policy includes an agreement among its member nations to impose a cap and trade system to meet the reductions required by the Kyoto Protocol. ${ }^{70}$ Yet, during the Bush Administration, even as our allies agreed to limit carbon dioxide emissions, the United States continued to insist that developing nations must commit to greenhouse gas reductions before the United States would take mandatory action. President Bush declared that the United States would look to economic growth to "provide[] the resources for investment in clean technologies." Some commentators described this position as stating that "growth is the solution and not the problem."72 The Bush Administration's position aligned with the historical view of the oil and gas industries, a "business as usual approach" that failed to take into account the damages associated with greenhouse gas emissions. ${ }^{73}$ In this sense, President Bush's position was not all that different from the 1997 Senate Resolution, which also called for opposing any international agreement that "would result in serious harm to the economy of the United States." 74

Even when the United States has passed related legislation, it has often fallen far short of European efforts. For instance, recent legislation in the United States now requires major automakers to meet an increased standard of thirty-five miles per gallon on aver-

able at http://unfccc.int/cop7/documents/accords_draft.pdf (draft unedited version).

70. See European Union Greenhouse Gas Emission Trading Scheme (2005), http://ec.europa.eu/environment/climat/emission.htm (last visited Mar. 10, 2008).

71. JACQUES \& LE TREUT, supra note 40, at 132 (citing a Feb. 14, 2002 statement by President Bush).

72. Id. at para. 1 .

73. See BROWN, supra note 24 , at 16 (recognizing similarities between the views of past administrations and the views of coal and petroleum interests); $c f$. HARVEY BLATT, AMERICA'S ENVIRONMENTAL REPORT CARD 151 (2005) (citing Ivan Illich) ("All our leaders now call themselves environmentalists. But their brand of environmentalism poses very few challenges to the present system.").

74. S. Res. 98, 105th Cong. (1997) (enacted). Notably, many American businesses have indicated that they are not opposed to emissions reduction measures. See, e.g., BILL MCKIBBEN, FigHT GLOBAL WARMING NOW 14 (2007) ("Business isn't opposed to action. One company after another has shown that it can cut carbon emissions and save money in the process."). 
age by $2020,{ }^{75}$ whereas Europe already requires an average of forty miles per gallon. ${ }^{76}$ As a result, the most significant efforts in the United States to address climate change have occurred at the state and local level. ${ }^{77}$ California has been particularly aggressive in passing state legislation to curb greenhouse gas emissions, and more than twenty other states have also pursued similar efforts. ${ }^{78}$ At the local level, more than 500 mayors have signed a pledge to undertake efforts to cut greenhouse gas emissions and to encourage action at the state and federal level. ${ }^{79}$ Unfortunately, their pleas for federal legislation have gone unanswered.

\section{The Leading Alternatives for Reducing Carbon Dioxide EMISSIONS}

There is no silver bullet for addressing global warming, but climatologists agree that the most important first step is to curtail the growth of carbon dioxide emissions and, as expeditiously as possible, to reduce carbon dioxide emissions. Even the Bush Administration, which steadfastly opposed any mandatory reductions in greenhouse gas emissions, eventually recognized the need to lower carbon dioxide emissions. ${ }^{80}$ The Administration's voluntary emissions reduction approach, most notably the ENERGY STAR program, produced some successes, such as when Wal-Mart Corpo-

75. Energy Independence and Security Act of 2007, Pub. L. No. 110-140, $§ 102,121$ Stat. 1492 (codified at 49 U.S.C. $\$ 32902$ (Westlaw 2008)).

76. E.g., Peter Fairley, The New CAFE Standards: Fuel Standards Will Likely Be Achievable but Won't Encourage Innovation, TECH. REV., Jan. 15, 2008, www.technologyreview.com/ Energy/20067.

77. See generally Kirsten H. Engel and Barak Y. Orbach, Micro-Motives and State and Local Climate Change Initiatives, 2 HARV. L. \& POL'Y REV 119 (2008) (cataloguing state and local efforts in the United States and analyzing incentives for state and local efforts that provide global, not local, benefits).

78. E.g., Eric Kelderman, Greenhouse-Gas Limits Gain Steam in States, STATELINE.ORG, May 1, 2007, http://www.stateline.org/live/details/story?contentId=203932.

79. See U.S. Conference of Mayors Climate Protection Agreement, http://www.usmayors.org/climateprotection/agreement.htm (last visited Mar. 10, 2008).

80. See generally Control of Emissions from New Highway Vehicles and Engines, Notice of Denial of Petition for Rulemaking, 68 Fed. Reg. 52,922-02, 52,931-33 (Sept. 8, 2003) (detailing the Administration's approach of creating "near-term voluntary actions and incentives" to reduce greenhouse gas emissions). 
ration installed energy efficient lighting systems in stores across the country. ${ }^{81}$

But the notion that voluntary measures, even with government support, can produce the necessary reductions in greenhouse gas emissions is beyond wishful thinking. Indeed, during the eight years of the Bush Administration, carbon dioxide emissions in the United States continued to grow. ${ }^{82}$ As noted above, the United States remains a leading source of greenhouse gas emissions, and it is unlikely that the developed world will agree to mandatory reductions in 2012, if the United States has not taken steps to reduce its emissions before then. The new President and Congress in 2009 face the imperative of adopting measures to control greenhouse gas emissions in the United States and thereby establishing American credibility for the international negotiations on the next climate change treaty.

This Part reviews the leading alternatives for reducing carbon dioxide emissions. This analysis begins with an evaluation of possible regulatory approaches under the Clean Air Act that could be utilized to reduce carbon dioxide emissions. This Part then outlines the market-based approaches of a carbon tax and cap and trade, which could be implemented to reduce carbon dioxide emissions in the United States.

\section{A. Regulatory Limits on Carbon Dioxide Emissions}

Historically, the United States has imposed regulatory controls to curtail pollution through a combination of regulatory emission controls, technology-forcing requirements, and permit limits. Environmentalists have long argued that the Clean Air Act provides a vehicle for limiting carbon dioxide emissions. Now that the Supreme Court has made clear that carbon dioxide falls within the

81. See Press Release, Wal-Mart Corporation, Wal-Mart Named ENERGY STAR partner (Aug. 2, 2001), available at http://www.walmartfacts.com/articles/3809.aspx. The federal government's ENERGY STAR program has been called the "crown jewel" of voluntary emission reduction programs, resulting in greenhouse gas emission reductions during 2004 that were equivalent to eliminating 23 million cars in the United States. Tom Kerr, Voluntary Climate Change Efforts, in Global Climate CHANGE AND U.S. LAW 591, 605-06 (Michael B. Gerrard ed., 2007).

82. See, e.g., sources cited supra note 26. 
definition of an air pollutant, ${ }^{83}$ there are a number of ways that carbon dioxide emission controls could be imposed under the Clean Air Act, which the United States Environmental Protection Agency (EPA) acknowledged during July 2008, when it released an Advanced Notice of Proposed Rulemaking regarding the regulation of greenhouse gases under the Clean Air Act. ${ }^{84}$

\section{A National Ambient Air Quality Standard for carbon dioxide under} Title I of the Clean Air Act.

EPA could identify carbon dioxide as a criteria pollutant and set a National Ambient Air Quality Standard (NAAQS) for carbon dioxide under Title I of the Clean Air Act. ${ }^{85}$ It is not readily apparent how an ambient air quality standard would be set for carbon dioxide, particularly since the United States, although a major emitter, is not the only source of harmful carbon dioxide emissions. But, theoretically, EPA might attempt to extrapolate an "acceptable" level of carbon dioxide emissions based on a target for carbon dioxide concentrations and a corresponding determination of how much carbon dioxide emissions may occur without exceeding that concentration. The Agency then could determine how much of the acceptable level of global carbon dioxide emissions should be allotted to the United States and in turn allocate those emissions on a per capita basis to the states for purposes of

83. In Massachusetts v. Envtl. Prot. Agency, 549 U.S. 497, 532 (2007), the Supreme Court held that greenhouse gases fit "well within the Clean Air Act's capacious definition of 'air pollutant.'"

84. See Advance Notice of Proposed Rulemaking, Regulating Greenhouse Gases Under the Clean Air Act, 73 Fed. Reg. 44,354 (July 30, 2008). While our discussion focuses on how EPA could regulate carbon dioxide emissions under the Clean Air Act, Congress also could enact new legislation providing comparable authority to EPA to regulate emissions. We believe that the Clean Air Act already provides adequate authority for traditional regulation of greenhouse gas emissions, and the Supreme Court has so held with regard to emissions from motor vehicles, so we do not discuss alternative statutory schemes that could be enacted. See.Massachusetts v. Envtl. Prot. Agency, 549 U.S. at 532.

85. See 42 U.S.C. $\$ 7408$ (Westlaw 2008) (criteria pollutants), 42 U.S.C. $\$ 7409$ (Westlaw 2008) (National Ambient Air Quality Standards). In 2003, the attorneys general of Massachusetts, Connecticut, and Maine filed notice of intent to sue EPA to require the agency to regulate carbon dioxide under 42 U.S.C. $\$ \$ 7408-09$, but later voluntarily terminated their suit without prejudice pending a determination of whether EPA had the authority to regulate carbon dioxide emissions under the Clean Air Act. Jonathan S. Martel \& Kerri L. Stelcen, Clean Air Act Regulation, in Global Climate Change and U.S. LaW, supra note 81 , at $144-45$. 
setting a NAAQS. If EPA were to do so, the states would be required to modify their Clean Air Act State Implementation Plans ${ }^{86}$ to indicate how they would meet the new NAAQS for carbon dioxide.

One advantage of using the existing NAAQS approach under Title I of the Clean Air Act is that it would not require new legislation, although EPA would need to pursue a rulemaking to identify carbon dioxide as a criteria pollutant (and to set an appropriate ambient air quality standard for carbon dioxide). Another advantage is that, while Title I only has been used for six pollutants to date ${ }^{87}$ it is a well-established method of addressing air pollution in the United States. A third advantage is that all sources of carbon dioxide emissions could be addressed, including activities beyond the burning of fossil fuels, such as deforestation, which contribute to the increase in carbon dioxide concentrations in the atmosphere. ${ }^{88}$ Yet another advantage, at least in some respects, is that implementation would be left to the states, which would allow each state to adopt the emission control programs that make sense given the unique features of the state's industrial base, energy use, and land use policies, as well as the availability of alternative energy in that state.

It is far from clear, however, that a meaningful National Ambient Air Quality Standard could be set for carbon dioxide. The NAAQS that have been set to date are based on toxicological findings regarding the harmful effects of the pollutants involved. ${ }^{89}$ While there is no question that carbon dioxide emissions will have harmful effects over time, their impact is generally less direct than the other criteria pollutants. Particulate matter, for example, is a criteria pollutant because it causes asthma and other respiratory

86. See 42 U.S.C. $\$ 7410$ (Westlaw 2008).

87. EPA has identified carbon monoxide, lead, nitrogen oxide, ozone, particulates, and sulfur dioxide as criteria pollutants under 42 U.S.C. \$ 7408. Envtl. Prot. Agency, National Ambient Air Quality Standards (NAAQS), http://epa.gov/air/criteria.html (last visited Nov. 5, 2008).

88. See, e.g., IPCC REPORT, supra note 9, at 45 fig.SPM.3 (noting that carbon dioxide emissions from deforestation, organic decay, and peatlands account for over seventeen percent of global anthropogenic greenhouse gas emissions, although much of these emissions occur outside of the United States in the less developed parts of the world).

89. See generally 40 C.F.R. $\$ 50$ (2008). 
difficulties. Carbon dioxide emissions, on the other hand, lead to harmful global warming, but it is the effects of the resulting climate change, not the carbon dioxide emissions themselves, that cause significant health effects. In this regard, carbon dioxide is unlike other pollutants that are regulated under the Clean Air Act; indeed, absent the greenhouse effect, carbon dioxide would not be considered a pollutant. ${ }^{90}$

Moreover, it is the aggregate effect of carbon dioxide emissions that is so damaging, because of the resulting build-up of carbon dioxide concentrations in the atmosphere. As a result, each state contributes to the global warming problem, yet the Clean Air Act concepts of "attainment" and "non-attainment" with ambient air quality standards would have little meaning where carbon dioxide emissions are involved. For traditional air pollutants, attainment means that air quality within that state (or regions within the state) is within acceptable limits from a human health standpoint; the air is "safe" to breathe. But safe levels of carbon dioxide emissions can only be attained when emission reductions occur throughout the United States-and the rest of the world. ${ }^{91}$

\section{Carbon dioxide emission standards for motor vehicles under Title II of the Clean Air Act.}

As argued by the combination of environmental groups and states that sought the petition for rulemaking addressed by the Supreme Court in Massachusetts $v$. EPA, the government could limit

90. While carbon dioxide might not be considered a pollutant, absent climate change, carbon dioxide emissions limit the effectiveness of the Clean Air Act's regulation of ozone and its pollutant precursors. Increased temperatures from carbon dioxide, and the associated increases in atmospheric water vapor, increase the formation of ozone in the lower atmosphere. For a given level of smog precursors (already regulated under the Clean Air Act), carbon dioxide pollution directly increases the health impacts from the resulting ozone. See Mark Z. Jacobson, On the Causal Link Between Carbon Dioxide and Air Pollution Mortality, 35 GEOPHYS. RES. LETTERS L03809 (2008).

91. An alternative method of controlling greenhouse gas emissions under Title I of the Clean Air Act would be for EPA to set New Source Performance Standards (NSPS) for Carbon Dioxide under 42 U.S.C. $\$ 7411$ (Westlaw 2008). Under the NSPS program, carbon dioxide emission limits could be imposed on newly constructed facilities, or on facilities that underwent major modifications. NSPS controls might help limit the growth of carbon dioxide emissions; however, they would not lead to significant reductions from existing sources of carbon dioxide emissions. See generally Martel \& Stelcen, supra note 85, at 145-47. 
carbon dioxide emissions from motor vehicles. Title II of the Clean Air Act requires EPA to regulate "the emission of any air pollutant from any class or classes of new motor vehicles or new motor vehicle engines, which in [the Administrator's] judgment cause, or contribute to, air pollution which may reasonably be anticipated to endanger public health and welfare." ${ }^{92}$ As noted above, the Supreme Court already has held that carbon dioxide is an "air pollutant" under the Clean Air Act, ${ }^{93}$ and EPA arguably has made the requisite endangerment finding in the course of refusing to grant a waiver for California's effort to regulate carbon dioxide emissions from automobiles in California. ${ }^{94}$

There are compelling arguments for regulation of carbon dioxide emissions from motor vehicles under the Clean Air Act, not the least of which is that the text of the statute requires it once EPA makes the requisite endangerment finding. ${ }^{95}$ Carbon dioxide emissions from motor vehicles account for approximately one-fourth of annual carbon dioxide emissions in the United States. ${ }^{96}$ As a result, by requiring more stringent emission controls under Title II of the Clean Air Act, EPA would address a leading source of carbon dioxide emissions. Emission controls for motor vehicles could be expected to have a significant effect on greenhouse gas emissions, once the requisite pollution control devices were developed and implemented in new motor vehicles.

But even if EPA were to exercise its authority to limit motor vehicle emissions under the Clean Air Act, meaningful carbon diox-

92. 42 U.S.C. $\$ 7521$ (a) (1) (Westlaw 2008), as quoted in Massachusetts v. Envtl. Prot. Agency, 549 U.S. 497, 528 (2007).

93. Massachusetts v. Envtl. Prot. Agency, 549 U.S. at 500.

94. See California State Motor Vehicle Pollution Control Standards; Notice of Decision Denying a Waiver of Clean Air Act Preemption for California's 2009 and Subsequent Model Year Greenhouse Gas Emission Standards for New Motor Vehicles, 73 Fed. Reg. 12,156-01 (Mar. 6, 2008). While EPA claims it did not make an endangerment finding when it rejected California's waiver request, the denial states that "warming of the climate system is unequivocal" and notes the likelihood of global sea level rise, heat waves, intense weather, wildfire, and insect outbreaks that arguably are tantamount to an endangerment. finding. Id. at 12,165.

95. Massachusetts v. Envtl. Prot. Agency, 549 U.S. at 533.

96. Advance Notice of Public Rulemaking, supra note 85 at 44,403 (July 30, 2008) ("Transportation activities ... accounted for approximately $28 \%$ of all GHG emissions in $2006 \ldots . .$.$) .$ 
ide emission reductions from automobiles would not occur for some time. Any proposed rulemaking regarding carbon dioxide emissions from motor vehicles would take time to develop within EPA $^{97}$ and then would be the subject of extensive negotiations with the auto industry and environmental groups before EPA could issue a final rule. Once the rulemaking was completed, the auto industry would need time to develop the necessary technology to improve fuel economy and/or limit carbon dioxide emissions. As a practical matter, therefore, carbon dioxide emission limits for motor vehicles could not be effective for at least several years.

In addition, once motor vehicle emission limits became effective, they only would affect new cars; existing cars, manufactured at a time when there were no carbon dioxide emission limits under the Clean Air Act, would not be affected. With many Americans owning their cars longer ${ }^{98}$-and new vehicles likely to be more expensive because of the cost of installing better pollution control equipment ${ }^{99}$-it would be several years more before the majority of cars were lower emission vehicles. As a result, while emission controls for motor vehicles warrant consideration as part of a comprehensive effort to limit greenhouse gas emissions, they would not be an effective measure for immediate reductions of carbon dioxide emissions. ${ }^{100}$

97. Cf., e.g., Robert L. Glicksman, Balancing Mandate and Discretion in the Institutional Design of Federal Climate Change Policy, 102 Nw. U. L. REv. 196, 209 (2008) (recognizing that in general agencies often have an incentive "to delay in issuing regulations").

98. E.g., Joseph Siano, 533,000 Miles and It Runs Like a Top, N.Y. TIMES, June 3, 2007, at 4 ("[C]ars are indeed staying on the road longer.").

99. For instance, fuel-efficient hybrid vehicles currently cost more up front than their gas-only counterparts, although when long-term costs are taken into account, hybrids may be a better deal. See, e.g., Douglas MacMillan \& Matt Vella, Hybrids Cost-Efficient over Long Haul, BUS. WK., Jan. 9, 2007, available at http://www.businessweek.com/autos/content/ jan2007/bw20070108_774581.htm ("A study released today by auto industry analysts at IntelliChoice shows that all of the 22 hybrid models currently sold in the U.S. will save owners money thanks to lower total cost of ownership, compared with competing vehicles."). Nonetheless, because up front costs often play a disproportionately large role in consumer choice, many consumers may be unwilling to pay extra for long-term savings. See, e.g., Sven Gustafson, Slow Hybrid Vehicle Sales Growth Predicted, Bus. REv., Jan. 31, 2008, available at http://www.mlive.com/naias/index.ssf/2008/01/slow_hybrid_vehicle_sales_ grow.html (noting than consumers have become accepting of high gas prices and are often unwilling to pay a premium for hybrid vehicles).

100. Reductions in carbon dioxide emission levels from automobiles may take time under any approach, because of the relative inelasticity of demand for gasoline (particu- 
3. Permits for major sources of carbon dioxide emissions under Title $V$ of the Clean Air Act.

EPA and the states could develop a permitting program for carbon dioxide emissions under Title $\mathrm{V}$ of the Clean Air Act. ${ }^{101} \mathrm{~A}$ permitting program would be targeted at major stationary sources that emit carbon dioxide (e.g. power plants, factories, and other industrial facilities). The states already have authority to regulate air pollutants from these facilities under Title $\mathrm{V}$ of the Clean Air Act, much as they regulate discharges of water pollutants under the National Pollutant Discharge Elimination System of the Clean Water Act. Facilities with Title V permits for carbon dioxide emissions would be required to report their emissions to the state issuing the permit on a regular basis and would face the possibility of violation notices or enforcement actions if they failed to comply with their Title $\mathrm{V}$ permits.

An advantage of using the Title $\mathrm{V}$ permitting system to regulate carbon dioxide emissions, as opposed to making carbon dioxide a criteria pollutant under Title $\mathrm{I}$, is that Title V limits might be easier for the states to implement, since they would target the individual facilities that are the greatest sources of carbon dioxide emissions. Indeed, if Title $\mathrm{V}$ permits were implemented alongside Title II limits on motor vehicle emissions, EPA and the states could address the most significant sources of carbon dioxide emissions without many of the administrative hurdles (and legal challenges) that would be faced if carbon dioxide were identified as a criteria pollutant. In addition, if Title $\mathrm{V}$ permits incorporated technologyforcing performance standards, they might allow the states to encourage innovation at both existing and new facilities.

A permitting system under Title $\mathrm{V}$, however, would have many of the same shortcomings as motor vehicle emission limits under Title II. First, a Title V permitting program would take time to develop and implement. The states would need to determine, in consultation with EPA, what level of carbon dioxide emissions could

larly in areas where there is insufficient mass transit). Our argument here simply is that market-based approaches would become effective much sooner-and therefore would provide incremental reductions of motor vehicle emissions more quickly-than motor vehicle emission controls enacted under Title II.

101. 42 U.S.C. $\S \S 7661-7661$ f (Westlaw 2008). 
be tolerated (much as would need to occur on a national level to set a Title I national ambient air quality standard). Second, the facilities that were covered by the permit requirement would need to apply for permits based on their historical emissions and the availability of technology to reduce their future emissions. Once permits were issued, legal challenges might ensue if the limitations were too stringent and, even without legal delays, facilities would need time to implement any changes that were required to meet the permit limits. As a result, emission reductions under Title $\mathrm{V}$ (like under Title II) would not be seen for several years.

Finally, while leaving regulation to the states has benefits in many other contexts, it is far less clear that state regulation is the best approach to a problem of national and international scope. To date, much of the climate change effort has occurred at the state and local levels, ${ }^{102}$ and those efforts are laudable, particularly in the absence of federal action during the Bush Administration. But experience tells us that the states vary widely in their approaches to environmental regulation, including the scope of their Title V permitting programs under the Clean Air Act. As a result, while a permitting program may be a helpful additional step to combat climate change, it is unlikely to be a strong enough measure to achieve the necessary level of overall emission reductions in the United States. ${ }^{103}$

\section{B. Market-Based Limits on Carbon Dioxide Emissions}

While regulatory tools are available to reduce carbon dioxide emissions, and their use may be desirable as part of a broad-based approach to climate change mitigation, most of the debate among policymakers and scholars has focused on market-based approaches to limit carbon dioxide emissions. The emphasis on market-based approaches may reflect in part the inherent complexity

102. See supra notes 78-79 and accompanying text.

103. See generally Jonathan B. Wiener, Think Globally, Act Globally: The Limits of Local Climate Policies 155 U. PENN. L. REV. 1961 (2007) (arguing that state-level action on climate change is not the best approach). Wiener advocates in favor of an international emissions trading program, which we believe would not be as effective as a carbon tax in addressing global climate change, but Wiener makes a compelling argument that individual state efforts are "of limited value, and may even yield perverse results." Id. at 1962. 
of the Clean Air Act and the delays that would face any regulatory system to reduce carbon dioxide emissions. Indeed, if past experience under the Clean Air Act is any guide, litigation would ensue once a new regulatory regime was established, leading to even greater delays in carbon dioxide reductions. ${ }^{104}$

\section{The benefits of market-based limits.}

The major driving force behind market-based approaches is the belief that harnessing market forces is critical to developing the operational changes and alternative technologies needed to reduce carbon dioxide emissions. Theoretically, reliance on market-based forces would allow development of the most innovative and cost-effective form of carbon dioxide reductions, which may be less likely to occur if the government mandates particular types of emission controls under the Clean Air Act or a comparable statutory scheme focusing on carbon dioxide emission controls. ${ }^{105}$

104. EPA proposed enacting regulations involving National Ambient Air Quality Standards in 1997, when the Agency lowered the ozone standards and added a standard for fine particulate matter. The new standards were immediately challenged, and the legal issues involved were not resolved under the Supreme Court's decision in Whitman v. Am. Trucking Ass'ns, 531 U.S. 457 (2001). There was also a contentious decision to lower the ozone standard in spring 2008. National Ambient Air Quality Standards for Ozone, 73 Fed. Reg. 16,436 (Mar. 27, 2008). Both environmental and industry groups were unhappy with the outcome, and the alleged political nature of the decision was widely criticized. See, e.g., Union of Concerned Scientists, EPA to Announce New Ozone Pollution Standard, Mar. 11 , 2008, http://www.ucsusa.org/news/press_release/epa-to-announce-new-ozone0100.html.

105. Many academics assume that market-based approaches will produce more innovation than traditional regulatory approaches. See, e.g., Stewart and Wiener, supra note 3. David Driesen challenges the assumption of market advocates, particularly their argument that emissions trading programs promote greater innovation. See Driesen, supra note 3. Driesen claims that cap and trade systems only promote innovation by companies that are selling credits and asserts that traditional regulation can promote innovation more effectively than emissions trading programs. David M. Driesen, Sustainable Development and Market Liberalism's Shotgun Wedding: Emissions Trading Under the Kyoto Protocol, 83 IND. L.J. 21, 5158 (2008). We agree with Driesen that cap and trade may limit innovation to sellers of credits and that technology-forcing performance standards can promote innovation effectively. We do not interpret Driesen's arguments to undermine our view that a carbon tax would provide incentives for innovation, however, particularly when combined with tax credits for alternative energy and carbon sequestration. Indeed, Driesen acknowledges that a carbon tax would promote more innovation than a cap and trade system. David M. Driesen, Economic Instruments for Sustainable Development in ENVIRONMENTAL LAW FOR SuSTAINABILITY: A CRITICAL RFADER 303 (Stepan Wood \& Benjamin J. Richardson eds., 2005). 
Some may question whether it is wise to rely on market forces to respond to a crisis that has been described as a market failure of epic proportions, since free market forces have failed to account for the enormous economic and social costs that would accompany global climate change. ${ }^{106}$ From an economic standpoint, however, carbon dioxide emissions are the classic externality: emissions occur at no cost to the emitting facility, but at an enormous cost to society as a whole. ${ }^{107} \mathrm{~A}$ central feature of the market-based approaches, therefore, is developing a price signal for carbon that incorporates the costs of that externality and drives the market toward finding acceptable alternatives. ${ }^{108}$

It may be a leap of faith to focus on market-based solutions for environmental problems that have their origins in the dramatic increase in carbon dioxide emissions that have accompanied industrialization and development around the world during the last 150 years. Yet, precisely because the increase in carbon dioxide emissions is occurring throughout the world and across all sectors of the global economy, a market-based approach may be the best way to address all sources of carbon dioxide emissions. ${ }^{109}$ In contrast, the regulatory approaches described above necessarily target individual market sectors, which may lead to uneven emission controls.

In addition to promoting cost-effective solutions, market-based limits allow the significant costs of carbon dioxide emission reductions to be distributed more evenly across the economy. Any carbon mitigation strategy will have economic impacts, ${ }^{110}$ and no approach can eliminate all disproportionate effects, but a market-

106. Executive Summary to STERN, supra note 38, at i ("Climate change presents a unique challenge for economists ....").

107. Id. at xviii.

108. For this reason, the IPCC states that "an effective carbon price signal could realize significant mitigation potential." IPCC REPORT, supra note 9, at 18.

109. The ability of a market-based approach to affect all sources of carbon dioxide emissions may depend on the use of an "upstream" market-based approach. See discussion infra, Part II.B.2. As a matter of regulatory design, a "downstream" approach also could reach all emission sources, but a downstream approach would be more susceptible to uneven controls, because of the volume and complexity of the sources involved.

110. Robert N. Stavins, A Meaningful U.S. Cap and Trade System to Address Climate Change 32 HARV. ENVTL. L. REV. 293, 296 (2008) ("Even a well-designed policy will ultimately impose annual costs on the order of tens and perhaps hundreds of billions of dollars."). 
based strategy is likely to allow costs to be shared most equally, because it affects the entire economy. Finally, a market-based approach can be implemented more rapidly than the regulatory approaches described above, particularly if a carbon tax is utilized.

\section{Upstream versus downstream market-based limits.}

Both a carbon tax and a cap and trade system could be imposed either "upstream" or "downstream." As Part III discusses in greater detail below, an upstream carbon tax or cap and trade system would focus on fossil fuel production (oil, coal, and natural gas), since together energy use accounts for approximately eighty percent of carbon dioxide emissions in the United States. ${ }^{111}$ An upstream market-based approach would have the greatest ability to ensure that all sources of carbon dioxide emissions are affected, because it focuses on carbon at the point that it enters the economy.

Alternatively, either a carbon tax or a cap and trade system could be imposed downstream on the facilities that are the major sources of carbon dioxide emissions. A downstream approach would focus on the same facilities that would likely be regulated under state implementation plans (if carbon dioxide became a criteria pollutant) or under Title $\mathrm{V}$ permits. A well-designed downstream approach could also reach all sectors of the economy, enabling costs to be distributed as evenly as an upstream approach.

The challenge under a downstream approach is the number and kinds of facilities that would be monitored and the inherent difficulty in reaching all forms of energy use, most notably motor vehicle use and electricity, which contribute significantly to carbon dioxide emissions. The broader range of facilities to be monitored would heighten the administrative complexity; the increased number of facilities would require greater resources for compliance assurance and enforcement. In addition, it is not clear how energy use by individuals would be addressed, despite their significant contribution to the carbon dioxide emissions problem. For these reasons, either a carbon tax or a cap and trade system would be easier to implement under an upstream approach, with a more

111. Advance Notice of Public Rulemaking, supra note 84, at 44,402. 
targeted approach to polluting facilities and motor vehicles perhaps coming over time through regulation under the Clean Air Act.

\section{Key features of a carbon tax and cap and trade.}

An upstream carbon tax arguably is the most straightforward approach to the global climate change problem. A carbon tax would be imposed on all oil, coal, and natural gas production in the United States, as well as all imports. The tax rate would be based on the marginal cost of carbon dioxide emissions (also referred to as the "social cost of carbon") 112 and would be increased annually to reflect the increase in the harmful effects of carbon dioxide emissions. A carbon tax thereby would provide a price signal that captures what is now an externality, namely the harmful effects of carbon dioxide emissions. ${ }^{113}$ Tax credits would be provided for carbon sequestration programs, which eliminate or reduce carbon dioxide emissions (and, in some circumstances, could be used to generate energy). Tax revenues would be used to expand tax credits for development of alternative energy and to address any regressive effects of the carbon tax.

If the carbon tax did not produce the desired reduction in carbon dioxide emissions, the tax would be increased; if the tax "overcorrected" and produced greater than anticipated reduc-

112. The IPCC reports that peer-reviewed estimates of the social costs of carbon dioxide emissions had an average value of $\$ 12$ per ton of carbon dioxide (or $\$ 43$ per metric ton of carbon). InTERgovernmental Panel On Climate Change, Climate Change

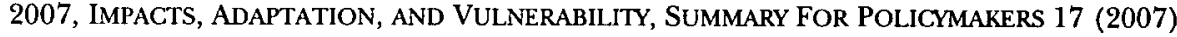
[hereinafter IPCC IMPACTS SUMMARY].

113. Existing carbon tax proposals reflect a range of carbon tax rates. For example, economist William Nordhaus proposes an initial tax of $\$ 7.40$ per ton of carbon dioxide (or $\$ 27$ per metric ton of carbon), with 2 to 3 percent annual increases. WILLIAM NORDAUS, A QUESTION OF BALANCE: WEIGHING THE OPTIONS ON GLOBAL WARMING POLICIES 15-16 (2008). Robert Shapiro proposes an initial tax of $\$ 14$ per ton of carbon dioxide (or $\$ 50$ per metric ton of carbon) with annual increases of approximately $\$ 2$ per ton of carbon dioxide. Robert SHAPIRO, NAM PhaM, \& ARUN MALIK, ADdREssing Climate Change WITHOUT IMPAIRING THE U.S. ECONOMY: THE ECONOMICS AND ENVIRONMENTAL SCIENCE OF COMBINING A CARBON-BASED TAX AND TAX RELIEF 15 (2008), http://www.climatetaskforce.org/pdf/CTF_CarbonTax_Earth_Spgs.pdf. The America's Energy Security Trust Fund Act of 2007, H.R. 3416, 110th Cong. (2007) would impose an initial tax of $\$ 15$ per ton of carbon dioxide (or $\$ 55$ per metric ton of carbon) with ten percent annual increases plus inflationary adjustments based on the cost-of-living index. 
tions, it could be decreased. ${ }^{114}$ Implementation and enforcement of a carbon tax would occur through existing programs within the Internal Revenue Service and the Energy Department. Moreover, by establishing a carbon tax in advance of any international agreement on global carbon dioxide emissions, the United States would meet its obligation to begin reducing its carbon dioxide emissions and establish much-needed credibility in the ensuing international negotiations.

An upstream cap and trade system would establish a cap on the carbon content of fuels in much the same way that an upstream carbon tax would impose a tax on those fuels. ${ }^{115}$ The cap would decline over time to achieve the desired level of carbon dioxide emission reductions. Where a cap and trade system becomes more complicated and, as Part III discusses, potentially unwieldy, is in the setting of baselines for the distribution of allowances and in the monitoring and enforcement of a complex allowance system.

Under an upstream cap and trade system, all producers and importers of fossil fuels would be required to have allowances to "cover" the carbon content of the fuels they produce. The number of those allowances would be limited by the overall "cap" imposed by the system. Allowances could be distributed either for free, through an auction system, or some combination. The leading cap and trade proposal in Congress, the Lieberman-Warner Climate Security Act of $2008,{ }^{116}$ would distribute the majority of allowances for free in the early years of the cap and trade system, with increasing percentages distributed by auction in subsequent years. Absent an auction, no revenue would be generated by cap and trade to support the development of alternative energy or carbon sequestration technologies. But, theoretically, market forces would provide a substitute for government subsidies: companies that developed alternative energy and otherwise found ways to limit their

114. Whether increases would be politically viable is, of course, one of the questions raised by a carbon tax, although similar questions also arise regarding whether firm caps will be politically viable if the price of carbon rises too high under a cap and trade system. See discussion infra, Part III.C.1.

115. See IPCC IMPACTS SUMMARY, supra note 112 , at 17.

116. Climate Security Act of 2008, S. Res. 3036, 110th Cong. (2008) (which substituted for America's Climate Security Act of 2007, S. Res. 2191, 110th Cong. (2007), for debate by the Senate in June 2008). 
carbon dioxide emissions would have "surplus" allowances that they could sell to companies that needed more allowances.

The best example of a cap and trade system on a national level in the United States is the cap and trade program under Title IV of the Clean Air Act, which was implemented under the Clean Air Act Amendments of 1990 to curtail acid rain. ${ }^{117}$ The acid rain program is widely viewed as an overwhelming success, both in terms of the environmental protection it provided and the degree to which change occurred without significant economic dislocation. Because the acid rain problem focused on 111 facilities in the Midwest (the so-called "Big Dirties"), however, we do not have experience in the United States-or the rest of the world-with an economy-wide cap and trade system. ${ }^{118}$

In contrast to the limited experience in the U.S. with cap and trade, carbon taxes have been successfully implemented in a growing number of countries. Carbon taxes have been implemented in Quebec and British Columbia as part of Canadian efforts to meet the requirements of the Kyoto Protocol. In addition, Denmark, Finland, Italy, the Netherlands, Norway, and Sweden have introduced carbon taxes in combination with energy taxes. ${ }^{119}$ The existing carbon taxes are too new to draw meaningful conclusions about their long-term benefits, but many economists believe that a carbon tax would be the most effective method of reducing carbon dioxide emissions. ${ }^{120}$ Cap and trade systems for carbon dioxide emissions have been implemented by the European Union ${ }^{121}$ and on a regional basis in New England; ${ }^{122}$ in addition, seven Western

\section{See supra note 4 .}

118. In addition, while there is no doubting the success of the Title IV program, the technological advances necessary to combat acid rain were readily available and relatively inexpensive, which may not be the case with the technology required for carbon dioxide emission reductions.

119. David G. Duff, Tax Policy and Global Warming, 51 CAN. TAX. J. 2063, 2090 (2003).

120. See, e.g., N. Gregory Mankiw, One Answer to Global Warming: A New Tax, N.Y. TIMES, Sept. 16, 2007, at 6 . Economists tend to favor taxes because they provide the clearest price signal, unencumbered by factors like baselines, allowance allocation, and use of credits. As explained in Part III, we agree with this "purist" view, although there are at least some economists who nonetheless favor a cap and trade system. See, e.g., Stavins, supra note 110 .

121. See supra note 70.

122. Regional Greenhouse Gas Initiative: An Initiative of the Northeastern and Mid- 
states and four Canadian provinces have taken steps to develop a cap and trade system. ${ }^{123}$ As discussed in Part III, the European Union system has not been particularly successful to date, but that has not diminished enthusiasm in the United States and abroad for relying on cap and trade systems as the principal method of reducing carbon dioxide emissions.

\section{The CASE FOR A CARbON TAX}

Given the urgency of the global climate change problem, and the increasing acceptance of a cap and trade system as a desirable alternative, the argument could be made that a cap and trade system should be implemented in the United States (and abroad) without further delay. This Part provides a comparison between a carbon tax and a cap and trade system and concludes that a carbon tax is preferable to cap and trade. ${ }^{124}$

\section{A. The Theoretical Tradeoff}

Both a carbon tax and cap and trade are market-based mechanisms for curbing greenhouse gas emissions, and therefore have

Atlantic States of the U.S., http://www.rggi.org (last visited Mar. 10, 2008).

123. See MKT. AdVISORY COMM. TO THE CAL. AIR RES. BD., RECOMMENDATIONS FOR DESIGNING A GREENHOUSE GAS CAP-AND-TRADE SYSTEM FOR CALIFORNIA $50-52$ (2007) (recommending a cap and trade system to implement the Global Warming Solutions Act of 2006 and describing the Western Regional Climate Action Initiative); CAL. HEALTH \& SAFETY CODE $\$ \S 38500-99$ (Westlaw 2008).

124. For an excellent overview of the issues from a global perspective, see William D. Nordhaus, To Tax or Not to Tax: Alternative Approaches to Slowing Global Warming, 1 REV. ENVTL. ECON. \& POL'Y 26 (2007). See also Robert N. Stavins, Policy Instruments for Climate Change: How Can National Govermments Address a Global Problem, 1997 U. CHI. LEGAL F. 293 (1997); Richard B. Stewart, A New Generation of Environmental Regulation, 29 CAP. U. L. REV. 21 (2001). On environmental taxes, see generally DUFF, supra note 119; Roberta Mann, Waiting to Exhale? Global Warming and Tax Policy, 51 AM. U. L. REV. 1135 (2002); Gary E. Marchant, Freezing Carbon Dioxide Emissions: An Offset Policy for Slowing Global Warming, 22 ENVTL. L. 623 (1992); Henry van Ėgteren, Regulating an Externality-Generating Utility: Environmental Taxes Under Limited Information, 21 ENVTL. \& RESOURCE ECON. 107 (2002); Richard A. Westin, Understanding Environmental Taxes, 46 TAX LAW. 327 (1993). On the actual use of carbon taxes in the EU and elsewhere, see, e.g., Johan Albrecht, The Use of Consumption Taxes to Re-launch Green Tax Reforms, 26 INT'L REV. L. \& ECON. 88 (2006); Jose Marcos Domingues, Environmental Fees and Compensatory Tax in Brazil, 13 LAW \& BUS. REV. OF THE AM. 279 (2007); ORG. FOR ECON. COOP. AND DEV., ENVIRONMENTALLY RELATED TAXES IN OECD COUNTRIES 21-31 (2001); Andrew J. White III, Decentralised Environmental Taxation in Indonesia: A Proposed Double Dividend for Revenue Allocation and Environmental Regulation, $19 \mathrm{~J}$. ENVTL. L. 43 (2007). 
advantages over traditional regulatory controls, for the reasons explained above. ${ }^{125}$ However, a carbon tax and cap and trade also differ in one important theoretical dimension, as well as in many important practical ones. Cap and trade, because it imposes an overall cap on the level of emissions permitted in the economy, provides certainty as to the environmental benefit that results from its implementation (Benefit Certainty). However, precisely because it imposes a fixed cap without regard to the cost to the economy at large or to individual polluters of attaining that cap, cap and trade suffers from lack of certainty in regard to the cost it imposes (Cost Certainty). A carbon tax, on the other hand, provides Cost Certainty because the precise amount of the tax is set in advance. However, because the effect of imposing a carbon tax on greenhouse gas emissions is not knowable in advance, the carbon tax does not offer Benefit Certainty.

From a purely theoretical perspective, disregarding for the moment any political implications, it is not clear whether Cost Certainty or Benefit Certainty is more important. Some scholars have argued that a focus on Benefit Certainty is superior because it puts the emphasis on the environment rather than on the economics, but since any policy imposes important costs, it seems short-sighted and somewhat misleading to focus only on the benefits. ${ }^{126}$ It could also be argued on the other side that since the benefits of any policy to reduce greenhouse gas emissions are worldwide and longterm, while the cost of any policy adopted by the United States will be confined to the United States and immediate, it is more important to focus on the costs rather than the benefits.

Both cap and trade and a carbon tax can be adjusted to mitigate Cost and Benefit Uncertainty. A cap and trade regime can have provisions for borrowing and banking allowances which permit firms burdened with sudden cost increases (e.g., as a result of a spike in the price of allowances) to alleviate that cost without affecting the overall cap. However, if the price of allowances rises and remains high as the cap continues to be lowered, one can ex-

125. See discussion supra, Part II.B.3. See also Jesse Ratcliffe, Reenvisioning the Risk Bubble: Utilizing a System of Intra-Firm Risk Trading for Environmental Protection, 92 CAL. L. REV. 1779 (2004).

126. Stavins, supra note 110. 
pect to see political pressure to enact "safety valves" that prevent the cap from being lowered further, which would impair Benefit Certainty. ${ }^{127}$ Under a carbon tax, the tax rate can be raised or lowered as necessary to obtain the needed Benefit Certainty, although this requires overcoming political opposition every time the government seeks to raise the tax rate. ${ }^{128}$

This Article does not take a position regarding whether Benefit or Cost Certainty is more important as a purely theoretical matter. ${ }^{199}$ Rather, the stated preference for the carbon tax is based on practical observations regarding its implementation, and this Part now turns to a discussion of the practical advantages and disadvantages of the carbon tax, as compared to cap and trade.

\section{B. Advantages of a Carbon Tax}

\section{Simplicity.}

The leading cap and trade proposal pending in Congress is the Lieberman-Warner Climate Security Act of $2008 .{ }^{130}$ It is an exceedingly long and complicated bill of over three hundred pages. Other cap and trade proposals have similar lengthy and complex provisions over hundreds of pages. There are far fewer carbon tax proposals, but the leading one, sponsored by United States Representative John B. Larson, is seventeen pages long. ${ }^{131}$

127. See STEWART \& WIENER, supra note 3 , at 76.

128. From a public choice perspective, the relative simplicity of a carbon tax, particularly with regard to the number of sources that could be taxed, may make political opposition more intense-and more effective.

129. Most economists prefer a carbon tax to cap and trade, and the Congressional Budget Office has estimated that a carbon tax could be five times more cost-efficient than cap and trade. CONG. BUDGET OFFICE, PUBL'N. NO. 2930, POLICY OPTIONS FOR REDUCING $\mathrm{CO}_{2}$ EMISSIONS ch. 1 (2008); See also Kevin Doran \& Alaine Ginnochio, United States Climate Poligy: Using Market-Based Strategies to Achieve Greenhouse Gas Emission Reductions, ENVTL. \& ENERGY L. \& POL'Y J. 31 (forthcoming 2008), available at http://ssrn.com/ abstract=1015849; John Freebairn, Taxes or Tradable Permits to Reduce Greenhouse Gas Emissions (June 2008) (unpublished manuscript, paper presented at Musgrave Symposium, Sydney).

130. See Climate Security Act of 2008, S. Res. 3036, 110th Cong. (2008).

131. See America's Energy Security Trust Fund Act, H.R. 3416, 110th Cong. (2007). The length of legislative proposals is not determinative of their complexity if enacted, since the legislative process often adds complexity to what had been streamlined proposals. We simply note that, as originally conceived, a carbon tax is far more straightforward than cap and trade. 
Why is cap and trade so much more complicated than the carbon tax? A carbon tax is inherently simple: a tax is imposed at $\mathrm{X}$ dollars per ton of carbon content on the main sources of carbon dioxide emissions in the economy, namely coal, oil, and natural gas. (Other greenhouse gas sources, such as methane, are not included because energy accounts for nearly eighty-five percent of the 7147 million metric tons of greenhouse gases in the U.S. economy. ${ }^{132}$ ) The tax is imposed "upstream," i.e., at the point of extraction or importation, which means than it can be imposed on only about 2000 taxpayers (500 coal miners and importers, 750 oil producers and importers, and 750 natural gas producers and importers) ${ }^{133}$ Credits can be given to carbon sequestration projects and to other projects that reduce greenhouse gas emissions (although this would need to be addressed in a way that does not dilute the price signal or create undue complexity), and exports are exempted. Beyond that, the main question is what to do with the revenue, which will be discussed below.

Cap and trade, on the other hand, is inherently more complicated. While the cap can also be imposed "upstream," it has several features that require complexity. ${ }^{134}$ First, baselines need to be set for purposes of establishing the emissions cap. Second, the proposal needs to determine how allowances will be created and distributed, either for free or by auction. Free distribution requires deciding which industries receive allowances, while an auction requires a complex monitoring system to prevent cheating. Third, the trading in allowances needs to be set up and monitored: a system needs to be devised to prevent the same allowance from being used twice, and penalties need to be established for polluters who exceed their allowances. Fourth, if allowances are to be traded with other countries, the international trading of allowances would need to be monitored as well. Fifth, to prevent Cost Uncertainty,

132. Stavins, supra note 110, at 306 (referring to a U.S. Energy Information Administration analysis of 2005 emissions).

133. Id. at 21 tbl. 2 (citing CAMBRIDGE ENERGY RESEARCH ASSOCS., DESIGN ISSUES FOR MARKET-BASED GREENHOUSE GAS REDUCTION STRATEGIES (2006)).

134. All of these complicating features occur in the Stavins proposal, supra note 111, and in the various legislative cap and trade proposals. For an overview of the latter, see Victor B. Flatt, Taking the Legislative Temperature: Which Federal Climate Change Legislative Proposal is “Best"?, 102 NW. U. L. REV. 123 (2007). 
cap and trade proposals typically have complex provisions for banking and borrowing allowances, and some of them provide for safety valves. Sixth, offsets are needed for carbon sequestration and similar projects, and those are more complicated than credits against a carbon tax liability. Finally, most cap and trade proposals involve provisions for coordinating with the cap and trade policies of other countries, and for punishing countries that do not have a greenhouse gas emissions control policy. ${ }^{135}$

It is important to note that this difference in complexity is inherent in the two policies as initially proposed, before any legislative amendments and before any implementation and enforcement issues. A pure cap and trade system is inevitably more complex than any carbon tax.

Cap and trade is also relatively untried: we have never had an economy-wide cap and trade system, while we have extensive experience with economy-wide excise taxes on a wide variety of products, including gasoline. This is why Congressman Larson's carbon tax bill can simply envisage adding three new relatively short sections to the existing excise tax part of the Internal Revenue Code. ${ }^{136}$ Cap and trade, on the other hand, is a major new and separate piece of legislation. A new administration determined to implement cap and trade would probably have to take at least two years to get the program passed in Congress and set up for implementation, even with swift Congressional action, because of the inherent delays in the rulemaking process. A carbon tax can be enacted and enforced practically tomorrow. Given that we have already delayed action for decades, and that every year that passes makes the climate change problem more difficult to solve, a carbon tax may be preferable to cap and trade-as well as traditional regulatory approaches-based on timing concerns alone.

In addition to its inherent complexity, cap and trade also is more difficult to enforce. Under cap and trade, an elaborate mechanism would need to be set up to distribute and collect allowances and to ensure that allowances are real (a difficult task,

135. On the complexity of imposing tariffs to punish other countries, which may be a violation of the WTO agreements, see Copenhagen Seminar on Trade and Climate Change, June 18-20, 2008, Summary Notes: Session on Border Carbon Adjustments.

136. America's Energy Security Trust Fund Act, H.R. 3416, 110th Cong. (2007). 
especially if allowances from non-United States programs are permitted) and that polluters are penalized if they emit greenhouses gases without an allowance. A new administrative body would need to be set up for this purpose, or at least a new office within EPA, and new employees with the relevant expertise would need to be hired. A carbon tax, on the other hand, could be enforced by the IRS with its existing staff, which has the relevant expertise in enforcing other excise taxes.

Cap and trade also raises collateral issues that are not present in a carbon tax, such as the need for the Securities and Exchange Commission to enforce rules regarding futures trading in allowances. A good example is the tax implications of both policies. A carbon tax, as a federal tax, has no tax implications: it is simply collected and is not deductible. Allowances under cap and trade, on the other hand, raise a multitude of tax issues: What are the tax implications of distributing allowances for free? What are the tax implications of trading in allowances? Should allowance exchanges be permitted to avoid the tax on selling allowances? What amount of the purchase price of a business should be allocated to its allowances? If borrowing and banking occur, what are the tax consequences? Can allowances be amortized? None of these issues arise under a carbon tax.

\section{Revenue.}

A carbon tax by definition generates revenue. A relatively modest tax of $\$ 10$ per ton of carbon content is estimated to generate $\$ 50$ billion per year; the America's Energy Security Trust Fund Act envisages a tax of $\$ 16.50$ per ton and generates correspondingly more revenue. ${ }^{137}$ While the current federal budget deficit and even larger actuarial deficit may justify revenue raising measures in general, revenues from a carbon tax should be segregated and devoted to addressing any regressive effects of the tax and reducing greenhouse gas emissions. Some carbon tax proposals promise "revenue neutrality" and focus on eliminating regressive effects. ${ }^{188}$

137. Id. at $\S 2$; Stavins, supra note 111 , at 52.

138. See, e.g., Gilbert E. Metcalf, A Proposal for a U.S. Carbon Tax Swap: An Equitable Tax Reform to Address Global Climate Change (Hamilton Project, Discussion Paper No. 2007- 
We agree that regressive effects must be addressed but otherwise would use revenues from the carbon tax to provide tax credits for alternative energy development and more energy-efficient motor vehicles, since the positive externalities that result from such research and development means that funding is likely to be undersupplied by the private sector even with a carbon tax in place. Revenues could also be used to support carbon sequestration projects and other projects that reduce greenhouse gas emissions, like mass transit and green building. ${ }^{139}$

Segregating the revenue from a carbon tax and using the proceeds to support further greenhouse gas reductions is justified because it reduces Benefit Uncertainty, which is the most serious drawback of a carbon tax compared to cap and trade. In addition, segregating the revenue is likely to reduce some political opposition to raising taxes in general, at least to the extent that such opposition is based on the perception that government is wasteful. ${ }^{140}$

In theory, cap and trade can be used to generate the same amount of revenue as a carbon tax, if all the allowances are auctioned. In practice, however, all cap and trade proposals introduced in Congress, as well as most academic proposals and existing cap and trade programs in the United States and abroad, include some free distribution of allowances. ${ }^{141}$ For example, the EU cap and trade regime distributed ninety-five percent of the allowances for free, and most Congressional proposals distribute over half of the allowances for free. ${ }^{142}$ The reason is obvious: for politicians, a significant attraction of cap and trade is that it creates from noth-

12, 2007), available at http://www.brookings.edu/ /media/Files/rc/papers/2007/ 10carbontax_metcalf/10_carbontax_metcalf.pdf.

139. It could also be argued that the revenue from a carbon tax could be used to reduce other, less efficient taxes, thereby producing a "double dividend." See, e.g., Charles L. Ballard, John H. Goddeeris, \& Sang-Kyum Kim, Non-Homothetic Preferences and the NonEnvironmental Effects of Environmental Taxes, 12 INT'L TAX PUB. FIN. 115 (2005). However, this double dividend theory has been disputed among economists. See, e.g., Juergen G. Backhaus, The Law and Economics of Environmental Taxation: When Should the Ecotax Kick In?, 19 INT'L REV. L. \& ECON. 117 (1999). Given the US budget deficit (current and projected), we do not advocate reducing other taxes if a carbon tax is enacted.

140. See Robert W. Hahn, Greenhouse Gas Auctions and Taxes: Some Practical Considerations (Am. Enter. Inst., Ctr. for Reg. \& Mkt. Studies, Working Paper No. 08-12, 2008).

141. Flatt, supra note 134, at 141; Stavins, supra note 111.

142. Flatt, supra note 134, at 141. 
ing a new, scarce resource that they can use to reward their constituents and donors. But if allowances are distributed for free, cap and trade generates less revenue than a carbon tax, and this means less potential to support research and development, carbon sequestration, and other greenhouse-gas-reducing efforts.

Moreover, it seems unlikely that free allocation of allowances would produce the optimal reduction in greenhouse gas emissions. Some polluting industries are likely to get too many allowances, and that would affect the trading price of allowances. At the extreme, the result would be what occurred in Europe, where politicians created so many free allowances that no reduction fróm business as usual was required at all, the price of allowances collapsed, and the EU failed to meet its goals under the Kyoto Protocol.

A similar risk to free distribution of allowances under a carbon tax would be pressure from affected industries for tax exemptions. The process of enacting tax exemptions is more visible than the process of distributing free allowances, however, and any exemption to one of the three industries affected (coal, natural gas, and oil) would be met by resistance from the other two, hopefully resulting in no exemptions at all.

\section{Cost certainty.}

A carbon tax ensures Cost Certainty: the cost is the amount of the tax, and whatever the incidence of the tax (i.e., whether it can be passed on to consumers or not), the cost cannot rise above the tax rate. This enables businesses to plan ahead, secure in the knowledge that raising the tax rate beyond any automatic adjustment, which can be planned for, requires another vote in Congress that they can hope to influence.

A cap and trade regime, on the other hand, suffers from inherent Cost Uncertainty. While allowances may be initially distributed for free, the key question for polluting businesses that need to acquire allowances to address a reduction in the cap is what would be the future price of allowances. Existing cap and trade programs like the Southern California RECLAIM system for nitrogen oxide emissions, in which the allowance prices spiked in 2000 to more than twenty times their historical level, and the EU Emission Trad- 
ing Scheme (ETS), in which the price of allowances collapsed when it became clear that too many allowances had been distributed, illustrate the problem of Cost Uncertainty in cap and trade programs. ${ }^{143}$ Cost Uncertainty makes it inherently difficult for businesses to plan ahead. ${ }^{144}$ The fundamental problem is that the reduction in the cap that is built into cap and trade would necessarily make allowances more expensive. How much more expensive depends on the development of future technologies, which cannot be predicted with any accuracy over the longer time period (fifty years or more) required for a cap and trade program to achieve its environmental goals.

Cap and trade proponents argue that Cost Uncertainty can be mitigated by provisions for banking extra allowances for use in future years, and borrowing allowances from future years to use in the present. ${ }^{145}$ These provisions add complexity, and it is unclear whether they will be effective: in the early years of the program, there are few allowances to bank, while borrowing risks leaving the business with insufficient allowances in the future when the cap is lower.

Ultimately, the only sure way of preventing Cost Uncertainty in a cap and trade regime is to build in a "safety valve," which would permit businesses to receive or purchase at a fixed price additional allowances if the market price of allowances becomes too high. Several of the current proposals in Congress have such built-in safety valves. ${ }^{146}$ However, the problem with safety valves is that they sacrifice Benefit Certainty, which is the main advantage of cap and trade: by definition, providing extra allowances when the cap is lowered means raising the cap.

Even if a cap and trade program has no safety valve built into it from the start, the commitment to Benefit Certainty may be misleading. If the lowered cap begins to seriously hurt businesses and

143. Stavins, supra note 110, at 314; cf. Karl Ehrhart et al., The Role of Auctions and Forward Markets in the EU ETS: Counterbalancing the Cost-Inefficiencies of Combining Generous Allocation with a Ban on Banking, 5 CLIMATE POL'Y 31, 43 (2005) (recognizing that the EU ETS distributed more allowances than it should have from a cost-efficiency standpoint).

144. See, e.g., supra note 74 and accompanying text (noting that the possibility of certainty was one reason that many European businesses welcomed regulation in this area).

145. Id.

146. Flatt, supra note 134. 
the price of allowances spikes, one should expect strong pressure on politicians to stop lowering the cap. Benefit Certainty under cap and trade as implemented may therefore be an illusion, while Cost Uncertainty is very real. ${ }^{147}$

\section{Signaling.}

A carbon tax sends a clear signal to polluters: pollution imposes a negative externality on others, and you should be forced to internalize that cost by paying the tax. ${ }^{148}$ There is no ambiguity about the message that is intended to be conveyed. Greenhouse gas emissions are costly, and even if people are willing to pay the price, they should be aware of the societal cost they are imposing.

A cap and trade system, however, sends a different and more ambiguous message. On the one hand, its goal is to reduce greenhouse gas emissions. On the other hand, it achieves that goal by either allowing polluters to purchase the right to pollute (from the government or from each other), or to receive permits to pollute for free. The underlying message is that the government permits you to pollute as long as you are willing to pay. Of course, the message (and the cost.imposed) may be the same, regardless of whether a tax is-paid or whether an allowance is purchased, although it is not the same if allowances are distributed for free. Labels are important, however, and calling the cost a tax sends a different signal than calling it the purchase price for a right to pollute. ${ }^{149}$

Admittedly, most of the activities that give rise to greenhouse gases were until recently considered perfectly legitimate and even positive. Driving a car or riding an airplane has no inherent moral value, and operating an industrial plant creates jobs. But we now know that these activities involve an additional collective cost, and taxing them directly or indirectly forces us to acknowledge this

147. Kenneth C. Johnson, Beware of the Dogmatist: A Consensus Perspective on the Tax versus Cap Debate (Soc. Sci. Research Network Working Paper, 2008), available at http://ssrn.com/abstract=1154638.

148. Duff, supra note 119, at 2069 (citing ORG. FOR ECON. COOP. AND DEV., ENVIRONMENTALLY RELATED TAXES IN OECD COUNTRIES 21-31 (2001)).

149. For a response to the "right to pollute" critique, see generally Jonathan Remy Nash, Framing Effects and Regulatory Choice, 81 NOTRE DAME L. REV. 313 (2006). 
cost in an unambiguous way. Permitting polluters to purchase the right to pollute does not send the same signal.

\section{Disadvantages of a Carbon Tax}

\section{Political resistance.}

A primary reason that both presidential candidates supported cap and trade during the 2008 election, and that other political leaders and many academics support cap and trade, rather than a carbon tax, reflects concern that a carbon tax cannot get enacted because it is a tax. Politicians vividly remember the fate of the Clinton-Gore BTU tax proposal in 1993, and "to be BTU'd" has become the shorthand among Clinton Administration veterans for what happens to supporters of politically unpopular proposals. ${ }^{150}$

However, 2009 is not 1993. The public has shown overwhelming support in the United States for decisive action to curb greenhouse gas emissions. When asked, Americans express just as much willingness to support a carbon tax as a cap and trade regime (which is more difficult to explain). ${ }^{151}$ If a new administration were to propose a carbon tax in 2009 , the political consequences might be less than past experience suggests, especially if the revenue is segregated and used to reduce greenhouse gas emissions, although this clearly is the most significant practical challenge facing a carbon tax.

Moreover, opponents of cap and trade inevitably liken it to a carbon tax. If allowances are auctioned, or even if they have to be purchased from private parties, the resulting cost is likely to be passed on to consumers. Thus, cap and trade is not just more complicated, it is also subject to the same criticism as a carbon tax: it will "increase gas prices at the pump" - an argument every voter

150. See, e.g., David E. Rosenbaum, Few See Gains from Social Security Tour, N.Y. TIMES, Apr. 3, 2005.

151. See, e.g., Thomas E. Curry et al., A Survey of Public Attitudes Towards Climate Change and Climate Change Mitigation Technologies in the United States: Analyses of 2006 Results (Mass. Inst. of Tech. Lab. for Energy and the Env., Working Paper No. 2007-01, 2007), available at http://sequestration.mit.edu/pdf/LFEE_2007_01_WP.pdf; see also Kene Boun My, Francois Cochard \& Anthony Ziegelmayer, On the Acceptability of the Ambient Tax Mechanism: An Experimental Investigation (Jena Econ. Research Papers, Working Paper No. 2007-081, 2007); Helmuth Cremer, Philippe de Donder \& Firouz Gahvari, Political Sustainability and the Design of Environmental Taxes, 11 INT'L TAX \& PUB. FIN. 703 (2004). 
understands. If we are to mitigate greenhouse gas emissions, politicians will need to face down inevitable resistance whether they propose a carbon tax or cap and trade.

Much of the opposition to a carbon tax is likely to come from organized groups that stand to benefit from cap and trade. ${ }^{152}$ These include industry groups that can easily reduce their emissions and can therefore expect to derive income from selling excess allowances (which they envisage receiving for free), and Wall Street, which can imagine the hefty fees it will charge for arranging trades in allowances and futures trading to hedge against Cost Uncertainty. ${ }^{153}$ However, the carbon tax will also have its supporters, primarily industry groups that will suffer from Cost Uncertainty under cap and trade and would prefer the Cost Certainty provided under the carbon tax. ${ }^{154}$

\section{Benefit uncertainty.}

The main substantive disadvantage of a carbon tax compared to cap and trade is Benefit Uncertainty. There can be no assurance that any given tax level will result in the desired reduction in greenhouse gas emissions. If the desired benefit is not achieved, the tax may have to be raised, resulting in renewed political opposition, which could defeat the tax increase and thereby limit the environmental benefits of the tax.

However, there are several reasons not to reject the carbon tax because of Benefit Uncertainty. First, as pointed out above, cap and trade may in fact be subject to similar Benefit Uncertainty, because if costs rise too high one can expect pressure to adjust the cap, even if there is no built-in safety valve.

Second, the tax rate can in fact be adjusted. General experience with other taxes has shown that once a tax is in place, it is usually not as hard to raise its rate despite political opposition to

152. Robert Hahn \& Peter Passell, Time to Change US Climate Policy, 4.5 THE ECONOMISTS' VOICE art. 2 (2007), www.bepress.com/ev/vol4/iss5/art2/.

153. See Leila Abboud, Carbon King: Economist Strikes Gold in Climate-Change Fight, WALL ST. J., Mar. 13, 2008, at Al.

154. Martin A. Sullivan, Will Business Learn to Love the Carbon Tax?, TAX NOTES, May 26, 2008, available at http://www.taxanalysts.com/www/features.nsf/Articles/ B1E993AF2B99722D8525745F007A58D3?OpenDocument. 
tax hikes; this is why people say that "an old tax is a good tax." The United States income tax began in 1913 with a rate of one percent, and has been raised (and lowered) many times since then (although Americans have become increasingly unwilling to accept tax increases). The Value Added Tax (VAT), which is now the most important tax in the world, was typically introduced in over 100 countries at a much lower rate than the current one. ${ }^{155}$ If it becomes clear that the carbon tax rate needs to be raised to achieve the necessary reduction in emissions, and if voters remain convinced of the need to reduce emissions, historical experience suggests that the rate could be raised, notwithstanding the political challenges.

Finally, neither cap and trade (without a safety valve) nor a carbon tax can truly achieve Benefit Certainty, because the desired level of emissions ( $450 \mathrm{ppm}$ ) is based on worldwide emissions, not United States emissions. We can have the strictest cap and trade regime and suffer the full cost, but if China and India do nothing, we will not have Benefit Certainty.

From this perspective, in addition to reducing greenhouse gas emissions in the United States, both a carbon tax and a cap and trade system serve the essential function of persuading the rest of the world that we are serious, and therefore that they should cooperate in a global policy to curb greenhouse gas emissions. Both cap and trade and a carbon tax are equally useful from that perspective, but for the reasons explained above, a carbon tax can be implemented much faster than cap and trade and, therefore, is preferable from the standpoint of international leadership. Stated differently, Benefit Certainty requires bringing large developing countries to the bargaining table, and a carbon tax is better and faster in doing so than cap and trade.

\section{Tax exemptions.}

Proponents of cap and trade argue that it is better than a carbon tax because the political bargain over which industries will get relief from its cost has to be reached up front as part of the decision of how to allocate allowances. They also argue that a carbon

155. LIAM EBRILl ET AL., THE MODERN VAT 13-14 (2001). 
tax will be subject to pressure to enact permanent exemptions for affected industries, which will permanently weaken its effect and exacerbate its Benefit Uncertainty.

However, it is not clear that a carbon tax would necessarily be weakened by any exemptions. This Article supports a proposal that would apply the tax upstream to only three industries: coal, oil, and natural gas producers and importers. None of these three industries is in a particularly good position to argue for exemptions vis-à-vis the other two, and the ultimate incidence of the tax is too unclear for other industries to effectively argue for exemptions.

The choice between free allocation of allowances under cap and trade and exemptions under a carbon tax is similar to the familiar debate in the tax literature over whether direct subsidies or tax expenditures are superior. Tax expenditures are indirect subsidies delivered through tax reductions or exemptions. While the traditional view has favored direct subsidies because they are arguably more transparent and easier to administer, recently the consensus has shifted to view both types of programs as equally transparent, and so the choice between them comes down to administrative considerations, which generally favor tax expenditures that can be administered by the IRS. ${ }^{156}$

In the cap and trade versus carbon tax debate, the choice between free allowances and tax exemptions is simpler. Tax exemptions are not necessary at all, but if they are enacted they will be quite transparent and subject to criticism as giveaways to unpopular industries. They will also be relatively easy to administer by the IRS. Free allowances, on the other hand, are inherently more complicated to distribute and monitor, for the reasons given above. This debate therefore favors the carbon tax.

\section{Coordination.}

Another alleged advantage of cap and trade and disadvantage of the carbon tax is that it is easier to coordinate with the regimes

156. See Charles D. Patterson III, Environmental Taxes and Sibsidies: What is the Appropriate Fiscal Policy for Dealing with Modern Environmental Problems?, 24 WM. \& MARY ENVTL. L. \& POL'Y REV. 121 (2000); David Weisbach \& Jacob Nussim, The Integration of Tax and Spending Programs, 113 YALE L.J. 955 (2004). 
implemented by other countries, and especially the EU ETS. ${ }^{157}$ Proponents of cap and trade envisage direct transfers of allowances between the United States cap and trade and the EU ETS, as well as other potential cap and trade regimes in, for example, Canada. ${ }^{158}$

Coordination issues may become more significant over time, if cap and trade emerges as the dominant global approach to climate change mitigation. However, this advantage is largely illusory at present. The initial EU ETS has not been successful because too many allowances were distributed, and it is unclear whether its replacement will be more successful. ${ }^{159}$ Canada is still debating between cap and trade and a carbon tax. As a result, there currently is no global cap and trade regime for the United States to join.

Moreover, exchanging allowances with foreign cap and trade regimes exponentially increases the enforcement difficulties inherent in cap and trade. Foreign allowances would have to be carefully monitored and verified to prevent widespread cheating. This problem is exacerbated under the EU ETS because allowances are distributed "downstream" to many different polluters. A carbon tax, on the other hand, can easily be collected on imports and rebated on exports, and as long as it is also imposed on domestic production, it does not pose significant World Trade Organization compliance issues. ${ }^{160}$

If, as a result of enacting a United States carbon tax, the United States is able to participate in negotiating a worldwide accord on curbing greenhouse gases, and if that accord is built on a global cap and trade regime, then we can consider adopting a United

157. See generally Clare Langley-Hawthorne, An International Market for Transferable Gas Emission Permits to Promote Climate Change, 9 FORDHAM ENVTL. L. J. 261 (1998).

158. Stavins, supra note 111 , at 358 .

159. See generally Inho Choi, Global Climate Change and the Use of Economic Approaches: The Ideal Design Features of Domestic Greenhouse Gas Emissions Trading with an Analysis of the European Union's $\mathrm{CO}_{2}$ Emissions Trading Directive and the Climate Stewardship Act, 45 NAT. RESOURCES. J. 865 (2005).

160. Cinnamon Carlarne, The Kyoto Protocol and the WTO: Reconciling Tensions Between Free Trade and Environmental Objectives, 17 COLO. J. INT'L ENVTL. L. \& POL'Y 45 (2006); Andrew Green \& Tracey Epps, The WTO, Science and the Environment: Moving Toward Consistency, 10 J. INT'L ECON. L. 285 (2007); Robert Howse \& Antonia Eliason, DOMESTIC AND INTERNATIONAL STRATEgIES to ADDRESS Climate CHANGE: AN OVERVIEW OF THE WTO LEGAL ISSUES (forthcoming) (on file with authors). 
States cap and trade system to match with that regime. In the absence of such a regime, it would be unwise to enact cap and trade just because the EU has adopted a flawed cap and trade system.

\section{CONCLUSION}

The global climate change crisis will not be resolved simply by implementing a carbon tax or a cap and trade system-or by any other legislative approach. Fundamental changes in energy production, development, and conservation, as well as changes in transportation, land use, and natural resource policies, must be pursued alongside efforts to reduce carbon dioxide emissions.

An effective carbon mitigation strategy, however, will be the centerpiece of any successful program to combat global climate change. While the widespread embrace of cap and trade is a positive development after decades of inaction, before we move forward we should pause to consider whether a cap and trade system is the best approach to combating global climate change. This Article demonstrates that a better response to global climate change would be a carbon tax that is adjusted over time to achieve the necessary reductions in carbon dioxide emissions, as well as the corresponding improvements in alternative energy sources and land and resource management practices that are essential to conserving our planet for future generations. 